International Review of Social History 45 (2000), pp. 209-250

(C) 2000 Internationaal Instituut voor Sociale Geschiedenis

\title{
Currents of Italian Syndicalism before $1926^{*}$
}

\author{
CARL LEVY
}

Summary: This article discusses four areas of research essential for a measured evaluation of Italian syndicalism before the fascist dictatorship. The first section presents a synoptic historical account. The second section critically summarizes the literature on the sociology of Italian syndicalism. The third section disentangles the ideological influences upon Italian syndicalism. The fourth evaluates the uniqueness or otherwise of Italian syndicalism within prefascist industrial relations. The conclusion explains the marginalization of Italian syndicalism after I9I8 using international comparisons. This article provides a detailed critical bibliography of the literature on Italian syndicalism published since the I960s.

Since the I970s the historiography of Italian syndicalism has grown significantly in both quantity and sophistication, yet it is still difficult to present a global picture of Italian syndicalism's multiple identities. This article will identify four areas of research that are essential for this enterprise. The first section of this article presents a synoptic historical account of Italian syndicalism from the late I89os to 1918. One of the major problems with the study of Italian syndicalism is the lack of one text encompassing the entire movement before the establishment of the fascist dictatorship in

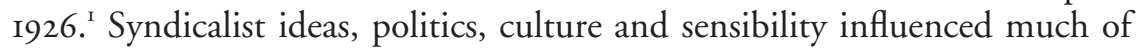

* I would like to thank the anonymous readers of earlier drafts of this article for their helpful comments. Dr Adrian Little was kind enough to read the final version. I thank him for his comments. Finally, many thanks to Marcel van der Linden and the IISG for supplying the photographs.

I. There are only two comprehensive published overviews of the entire history of Italian syndicalism before 1926, both of these are chapter-length accounts, see C.L. Bertrand, "Revolutionary Syndicalism in Italy", in M. van der Linden and W. Thorpe (eds), Revolutionary Syndicalism: An International Perspective (Aldershot, 1990), pp. I39-I54 and Maurizio Antonioli, "Il sindacalismo italiano rivoluzionario", in idem, Il sindacalismo italiano. Dalle origini al fascismo. Studi e ricerche (Pisa, 1997), pp. I25-I56. Two short overviews of Italian syndicalism up to I9I5 (Italy's entry into the First World War) are G.B. Furiozzi, Il sindacalismo rivoluzionario italiano (Milan, 1977) and A. De Clementi, Politica e società nel sindacalismo rivoluzionario I9oo-I9Is (Rome, I983). David Roberts concentrates on certain leaders and intellectuals in prewar syndicalism and focuses on their role in the development of fascism: see D. Roberts, The Syndicalist Tradition and Italian Fascism (Chapel Hill, NC, 1979). Alceo Riosa has written a careful account of the activities of the first syndicalists in the Italian Socialist Party in the first decade of the twentieth century: see A. Riosa, Il sindacalismo rivoluzionario in Italia e la lotta politica nel partito socialista nell'età giolittiana (Bari, 1976). There is an excellent bibliographical overview of studies (mainly in Italian) of Italian 
Italian culture and politics. It defined the language and emotions of both the internationalist maximalist socialism that gave birth to Italian communism and the populist radicalism that nurtured the politics of the early fascists. However, since the institutional history of Italian syndicalism is discontinuous, historians have found it difficult to present a coherent holistic account.

The second section of this article summarizes the sociological analyses of the diverse occupational groups attracted to Italian syndicalism. Recent crossnational surveys of the occupational groups attracted to syndicalism demonstrate a laudable open-mindedness. However, even these studies set parameters to the syndicalist universe. ${ }^{2}$ Similarly, as we will see, it is possible to draw certain conclusions without falling back on the older, cruder Marxist or functionalist methodologies.

The third section of this article will seek to disentangle the ideological influences which influenced Italian syndicalism, particularly anarchism and republicanism and the libertarian cultural network which sustained syndicalism within labour and social movements. The roles of the intellectuals and the educated middle classes in both pre-1926 Italian syndicalism and socialism have frequently been noted. However, a major weakness in the studies of Italian syndicalism, particularly Anglophone studies, is an excessive emphasis on certain intellectuals. ${ }^{3}$ The influence of syndicalist intellectuals on the Italian cultural avant-garde has probably been better understood than the exchange between labour movements and these individuals.

This leads neatly to the final section of this article which discusses the interplay between syndicalist labour organizations, strategies and politics and the net effectiveness of syndicalist action in strikes and collective bargaining. Was there anything unique in the practices and activities of syndicalist trade unionists that differentiated them from their socialist and nonsocialist competitors?

syndicalism from the I970s to the middle I990s: see A.O. Guerrazzi, "Il sindacalismo rivoluzionario in Italia (I904-I9I4): una bibligrafia orientativa", Rassegna di Storia Contemporaranea, 3 (I996), pp. I25-I53. For a review of the historiography, see G.B. Furiozzi, Le interpretazioni del sindacalismo rivoluzionario (Florence, 1985 ).

2. M. van der Linden and W. Thorpe, "The Rise and Fall of Revolutionary Syndicalism", in Van der Linden and Thorpe, Revolutionary Syndicalism, pp. I-24; M. van der Linden, "Second Thoughts on Revolutionary Syndicalism”, Labour History Review, 63 (1998), pp. I82-196. For an ambitious attempt to situate syndicalism within the broader currents of working-class social movements in Europe, see M. Mann, "Sources of Variation in Working-Class Movements in Twentieth Century Europe”, New Left Review, 2I2 (July/August 1995), pp. I4-54.

3. David Roberts's very good monograph (The Syndicalist Tradition) displays this weakness. An egregious example of this tendency is found in A.J. Gregor, Young Mussolini and the Intellectual Origins of Fascism (Berkeley, CA, 1979). An interesting balanced account of the relationship between futurism, syndicalism and anarchism can be found in G. Berghaus, Futurism and Politics: Between Anarchist Rebellion and Fascist Reaction, I909-I944 (Providence, RI, 1996), pp. 33-36, 5258. This study tries to distinguish between urban and provincial settings as well as intellectual circles and broader social movements. 


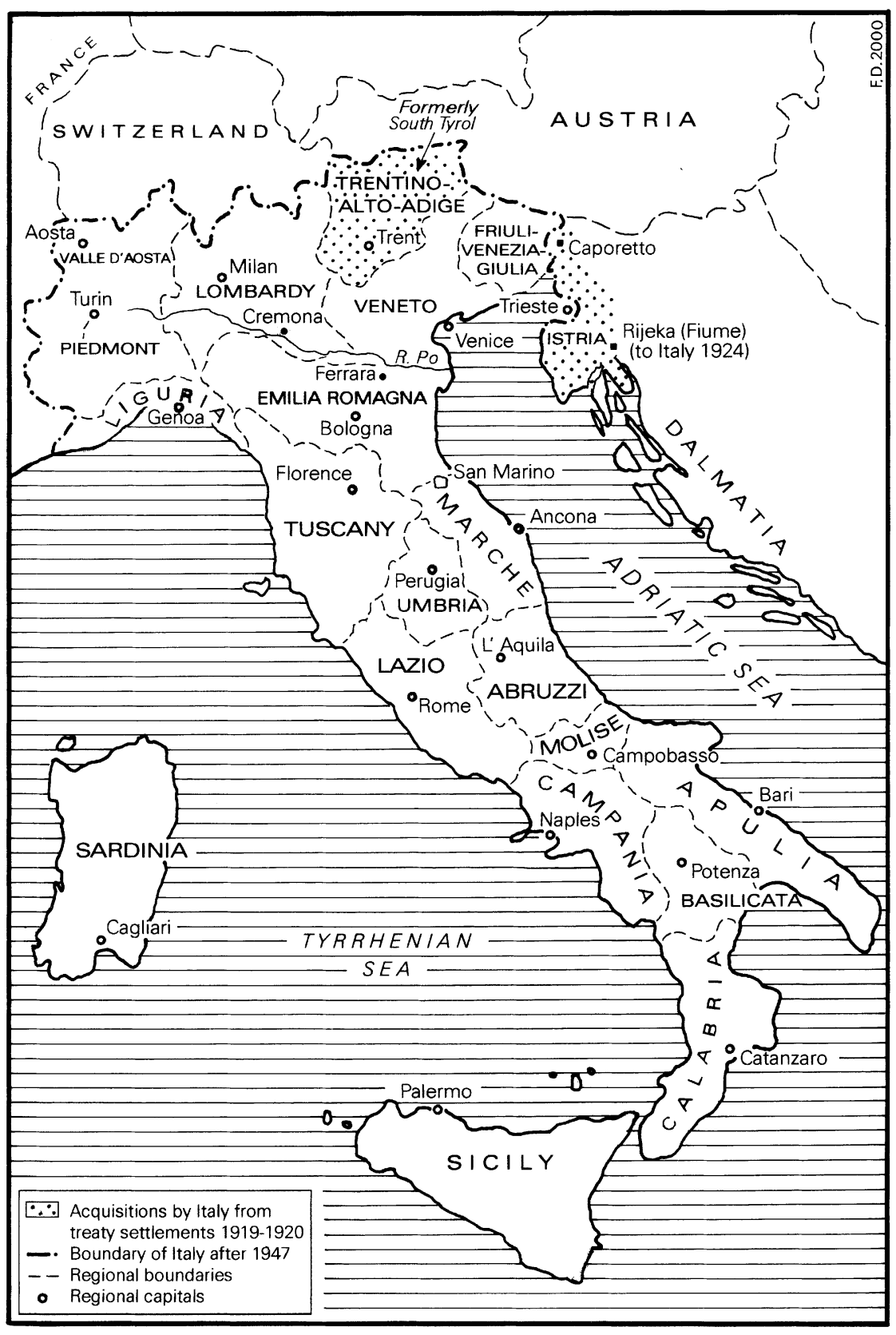

Figure I. Italy, first half of the twentieth century. 
One of the most fruitful ways forward for the study of Italian syndicalism are international comparative studies which use the Italian model as one of their chief case studies. Works concerning the international debate within pre-I9I4 syndicalism or the role of the Italian diaspora for the spread of syndicalism in Latin America, the United States and elsewhere should be highlighted. ${ }^{4}$ But these efforts have been limited by the parochial spirit still found in many Italian studies and the tendency in foreign comparisons to ignore or only briefly cite the Italian case and choose the French, Spanish, Latin American or northern European models instead. In order to show the fruitfulness of the international comparative approach, the conclusion of this article will therefore briefly discuss the decline of Italian syndicalism from the I920s onwards, by comparing its marginalization with other similar national examples.

\section{A SYNOPTIC HISTORY OF ITALIAN SYNDICALISM}

As a movement, Italian syndicalism appears so contradictory that a simple definition is illusive. Between the early I900s and 1915, Italian syndicalists embraced direct action and electoral politics. They assimilated the orthodox Marxist, Karl Kautsky, and the renegade, Georges Sorel. They praised the industrial working class of the northern cities, but excelled at organizing landless labourers in the Po Valley. They distrusted the Italian state, but admired the Italian traditions of municipal and communal politics. They denounced the militarist and monarchical liberal Italy, but were imbued with a strong sense of Risorgimento patriotism. It is impossible to give the reader a one-sentence definition of Italian syndicalism. Like Italian fascism, Italian syndicalism can only be understood by writing its history.

The history of Italian syndicalism from 1900 to 1918 can be divided into three phases. In the first phase, from approximately 1900 to $1906 / 1908$, the chief syndicalist current was located within the Italian Socialist Party (Partito Socialista Italiano, PSI) itself. In its second phase (1906/1908 to I9I2), Italian syndicalism was marginalized and expelled from the PSI and

4. Particularly important is Maurizio Antonioli's meticulously-researched work: see especially, "Sindacalismo rivoluzionario italiano e sindacalismo internazionale: Da Marsiglia a Londra (I9081913)", Ricerche storiche, 9 (198I), pp. I9I-240. See also A. Andreasi (ed.), L'anarcosindacalismo in Francia, Italia, Spagna (Florence, 1978). For the relationship between the IWW and Italian anarchists and syndicalists, see A. Dadà, "Aspetti del sindacalismo rivoluzionario statunitense: 'L'Industrial Workers of the World'”; B. Cartosio, "L'IWW nel sindacalismo rivoluzionario internazionale, I909-I9I4", Ricerche storiche, 9 (I98I); idem, "Gli emigrati italiani e L'Industrial Workers of the World”; in B. Bezza (ed.), Gli italiani fuori d'Italia (Milan, I983), pp. 359-395; D. Gallagher, All the Right Enemies: The Life and Murder of Carlo Tresca (New Brunswick, NJ, 1988); P. Avrich, Sacco and Vanzetti: The Anarchist Background (Princeton, NJ, 199I); idem, Anarchist Voices: An Oral History of Anarchism in America (Princeton, NJ, 1995). Donna Gabaccia has given us a very good overview of the literature: see D. Gabaccia, "Worker Internationalism and Italian Labor History, I870-I9I4", International Labor and Working-Class History, 45 (1994), pp. 63-79. 
its associated trades union confederation, the Confederazione Generale del Lavoro (CGL), but failed to create a coherent national organization to threaten socialist hegemony. In the third stage (1912-1916), the formation of the Unione Sindacale Italiana presented the Italian socialists and socialist trade unionists with a serious threat, but with the entry of Italy into the First World War in I9Is the USI was itself split between interventionists and antiwar factions. Eventually the interventionists formed a new organization, the Unione Italiana del Lavoro (UIL), which only became notably active in I9I8.

The origins of Italian syndicalism are found in a series of parallel developments whose synthesis distinguish it from other national movements. Although other syndicalist or syndicalist-like movements were influenced by the emergence of socialist parties affiliated to the Second International, the Italian case was unique because for a few years the pioneer Italian syndicalists were within the mainstream of ideological and political debate. ${ }^{5}$ The syndicalist current within the PSI drew its support from party militants and socialist intellectuals opposed to entry into Prime Minister Giolitti's liberal and reformist cabinets that followed the reactionary politics of the I89os. But since France was always an important model for much of the Italian left, the fate of socialists within the socially conservative Dreyfusard cabinets served a warning for the pioneer "socialist" syndicalists. At the same time, the German model (both the prestige of Germany's industrial prowess and that of the SPD), taught syndicalists other lessons. Liberalization of tradeunion legislation after I90I led to an explosion of union membership and to a strike wave in parts of northern Italy. However, the early syndicalists and their intransigent socialist allies were concerned that Giolitti's politics of incorporating the northern working class into the Italian state mimicked Bismarck's earlier attempts to coopt the German working class into the unreformed Prussian monarchy. After the heroic phase of persecution by Bismarck in the I88os, the SPD, especially its affiliated trade unions, appeared to avoid emphasizing institutional reform in Germany. Thus the trajectory of early Italian syndicalism was shaped by events in France and Germany. The resultant ideological characteristics of this "socialist" syndicalism set the tone for the variegated movement in the future. Italian "socialist" syndicalists differentiated themselves from other currents in the PSI through consistent demands for the institutional and constitutional reform of the Italian state. They adopted a republicanism derived from Mazzini and the French revolutionary tradition, while their early antiministerialism was nurtured from the negative conclusions they drew about the role of socialists in French national government and the disenchantment of Italian republicans with the liberal state which followed the Risorgimento. This is an area which cries out for greater study. Although we have excellent studies

5. This is the burden of Riosa's argument in Il sindacalismo rivoluzionario, pp. I5-I42. 
about the republican and Mazzinian origins of modern Italian socialism, we still lack a single monograph devoted to the republican tradition within Italian syndicalism, or for that matter, within the PSI itself. ${ }^{6}$

Emphasis on institutional reform by some of the early syndicalists did not mean that class-based issues were slighted. Former members of the Partito Operaio Italiano (the Italian Workers' Party) supplied the emergent movement with its proletarian élan in Milan and elsewhere in the industrial triangle. Here, too, international comparisons are instructive. The POI arose during the interregnum between the decline of the First International and the spread of models, practices and ideology associated with the Second International. ${ }^{7}$ It was a hybrid organization at times accommodating anarchists, municipal socialists and workerists. In this respect it fused two currents of practice associated in France with Jean Allemane and Paul Brousse; and this affinity was not only elective: there were direct exchanges and debates between the French and the POI which need more consistent examination. ${ }^{8}$

Finally, syndicalism gathered supporters within the local Chambers of Labour (camere del lavoro). There is an Italian genealogy that can be traced through the POI and the fasci siciliani (the mass social movement in Sicily during the I890s). ${ }^{9}$ However, placing too excessive an emphasis on this

6. For the relationship between Italian socialism and the republican tradition, see M.G. Gonzalez, Andrea Costa and the Rise of Socialism in the Romagna (St. Louis, MO, 1980); A. Berselli (ed.), Andrea Costa nella storia del socialismo italiano (Bologna, I982); M. Ridolfi, "Militanti e dirigenti del partito repubblicano nella Romagna post-unitaria”, Passato e Presente, I4-I5 (1987), pp. 75I08; idem, Il Partito della Repubblica. I repubblicani in Romagna e le origini del PRI nell'Italia liberale (I872-I895) (Milan, 1989); idem, Il circolo virtuoso (Florence, 1990); M. Degl'Innocenti, Cittadini e rurali nell'Emilia Romagna tra '800 e 'goo (Milan, 1990); G.B. Furiozzi (ed.), Le origini del socialismo nell'Italia centrale (Florence, 1993). Also see M. Tesoro, I repubblicani nell'età giolittiana (Turin, 1978); D. Mengazzi (ed.), Gli uomini rossi di Romagna. Gli anni della fondazione del PSI (I892) (Manduria, 1994). Roberto Vivarelli has noted the importance of the Mazzinian spirit for the ethos of Italian maximalist socialism during the biennio rosso. See his Storia delle origini del fascismo. L'Italia dalla grande guerra alla marcia su Roma, vol. 2 (Bologna, 199I), pp. 360-384, $4 \mathrm{I} 7$.

7. For the POI, see L. Briguglio, Il Partito Operaio Italiano e gli anarchici (Padua, 1969); D. Perli, I congressi del POI (Padua, I972); M.G. Meriggi, Il Partito Operaio Italiano. Attività, revendicativa, formazione e cultura dei militanti in Lombardia, I880-I89o (Milan, 1985); L. Tilly, Politics and Class in Milan I88I-I90I (Oxford, I992), chs 8 and 9.

8. For ideological affinities and circulation of ideas between Italy and France during this "interregnum", see D. Stafford, From Anarchism to Reformism: A Study of the Political Attitudes of Paul Brousse within the First International and the French Socialist Movement, 1870-90 (London, 1971); L. Valiani, Questioni di storia del socialismo (Turin, I975), pp. 80-90; E. Civolani, L'anarchismo dopo la Comune (Milan, 1981); K.S. Vincent, Between Marxism and Anarchism: Benoît Malon and French Reformist Socialism (Berkeley, CA, 1992); G. Berti, Francesco Saverio Merlino. Dall'Anarchismo socialista al socialismo liberale (Milan, 1993).

9. For the fasci siciliani, see various authors, I fasci siciliani (Bari, 1975), vols I-2; F. Renda, I fasci siciliani (Turin, 1977); N. dell'Erba, Giornali e gruppi anarchici in Italia (I892-1900) (Milan, I983); S. Costanza, "'Socialismo rurale' e Sicilia contadina dai fasci alla vigilia della guerra, I894-1914", in G. Cingari and S. Fedele (eds), Socialismo nel mezzogiorno d'Italia, I892-I926 (Bari, 1992), pp. 
would ignore rich and important international anarchist influences. In both France and Italy the anarchists entered labour organizations due to their frustration with the terrorist strategies of the I89os which had marginalized anarchism in both countries. Within the Italian context Saverio Merlino and Errico Malatesta led anarchists back into the labour movement, but the forced exile of hundreds of anarchists from France, Italy and Spain during the I89os facilitated the exchange of ideals, ideologues and models of organization that is an essential episode in the prehistory of European syndicalism. As I have shown elsewhere, from his exile in London Malatesta guided Fernand Pelloutier towards his conception of the bourses du travail, which would serve as the first framework for French syndicalism in the late I89os and early 1900s. ${ }^{\text {I0 }}$ Ironically, the most prominent advocate of this key institution of French syndicalism may have had an Italian exile mentor; a teacher, one should add, who became increasingly unhappy with his student's handiwork.

Comparisons with France also help place the reformist origins of the bourses du travail in a clearer context. A much praised history of the bourses expresses surprise that these putatively revolutionary organizations were dependent upon municipal grants to survive. ${ }^{\mathrm{II}}$ But a similar pattern can be noted in the Italian case. In Turin, for example, the camera del lavoro was aided by middle-class reformers who envisaged it as an ideal institution to regularize a chaotic labour market still dominated by the hectic flow of migrants from the countryside. ${ }^{12}$ In both settings reformists saw the bourses and the camere exercising the ameliorative but not threatening function that large trade unions carried out in Britain. However, in Italy (and France) local anarchist or libertarian political cultures radicalized these very popular institutions during the I900s.

The anarchists spread the celebration of May Day and associated it with the "syndicalist" general strike. The anarchists in Italy promoted the nonsectarian and antistatist flavouring of the camere, thereby allowing syndicalists to find a home there, albeit, paradoxically, the "socialist" syndicalists within the PSI itself were marginalized in the wake of the first syndicalist-inspired general strike of 1904 in which the camere del lavoro played a primary role. In response the antisyndicalist socialist trades union congress, the CGL, was established in 1906. Nevertheless, until the expulsion of syndicalists from the CGL in 1906 and the PSI in 1908, the ideology of mainstream Italian socialism was directly and indirectly influenced by the syndicalists. Indeed

329-347; N. Pernicone, Italian Anarchism I864-I892 (Princeton, NJ, I993), pp. 283-285; various authors, Il fasci dei lavoratori e la crisi italiana di fine secolo (1892-1894) (Caltanisetta [etc.], I995). Io. C. Levy, "Malatesta in Exile", Annali della Fondazione Einaudi, I5 (I98I), pp. 245-270; idem, "Malatesta in London: The Era of Dynamite", in L. Sponza and A. Tosi (eds), A Century of Italian Emigration to Britain I880s to I980s: Five Essays, supplement to The Italianist, I3 (1993), pp. $25-42$. II. P. Schöttler, Naissance des bourses du travail (Paris, I988).

I2. I deal with the case of Turin in my Gramsci and the Anarchists (Oxford, 1999), pp. 25-32. 
in its first phase Italian syndicalism's main publicists appeared to endorse their own version of orthodox Marxism.

Unlike the New Left in the Netherlands, Sweden or Germany, Kautskyite orthodoxy itself was given pride of place in the Italian debates. Marxist ideological positions were fluid and nebulous in Italy. Kautsky attracted a wide and odd assortment of leaders and intellectuals, not so much for the minutiae of his arguments but because they seemed rigorous, consistent and the embodiment of scientific socialism. ${ }^{13}$ For the nonsyndicalist opponents of the reformism of Filippo Turati, such as Oddino Morgari or Enrico Ferri, this merely meant glossing over their positivist anticlericalism with a veneer of Marxist rhetoric. The syndicalist ideologues within the PSI, such as Arturo Labriola ${ }^{\mathrm{I} 4}$ and Enrico Leone, ${ }^{\mathrm{Is}}$ took Kautsky the most seriously! This first, professorial, syndicalist leadership was attracted to Kautsky because they felt the northern positivists were too friendly to a fellow northerner, Giolitti, and his form of patronage politics. The German theorist seemed to offer a critique of the modern capitalist state which they could assimilate to their particular concerns about Italy's monarchical-bureaucratic state. In particular, Arturo Labriola advocated a parliamentary strategy involving a push towards universal suffrage. Indeed it was only with the defeat of syndicalism as a party faction within the PSI, sealed by the official expulsion of the theoreticians in 1908, that syndicalism appeared in the more conventional costume of direct action, opposing but even now not completely abandoning electoral strategies.

The foundation of the CGL in 1906 helped to give the new craft foundations, such as FIOM (Federazione Italiana Operai Metallurgici, the metalworkers' and engineers' federation), greater power to control the

13. For the origins of May Day in Italy, see M. Antonioli, Vieni o Maggio: aspetti del Primo Maggio in Italia tra Ottocento e Novecento (Milan, 1988). For the diffusion of Marxism in Italy, see G. Turi, "Aspetti dell'ideologia del PSI (I890-19I0)", Studi storici, 2I (1980), pp. 67-94; F. Andreucci, "The Diffusion of Marxism in Italy during the Nineteenth Century", in R. Samuel and G. Stedman Jones (eds), Culture, Ideology and Politics (London, 1982), pp. 214-216; M. Ridolf, "L'industria della propaganda' e il partito: stampa e editoria nel socialismo italiano prefascista", Studi storici, 33 (1992), pp. 33-80; P. Favilli, Storia del marxismo italiano. Dalle origini alla grande guerra (Milan, 1996). The early history of Italian syndicalism is covered in the unpublished Ph.D. of C.L. Bertrand, "Revolutionary Syndicalism in Italy, I9I2-1922" (Ph.D., University of Wisconsin, 1969), pp. I-27.

I4. There is only one complete biography of Antonio Labriola: see D. Marucco, Arturo Labriola e il sindacalismo rivoluzionario in Italia (Turin, 1970). His adventurous life would repay another attempt. His ideas are discussed in: E. Santarelli, La revisione del marxismo in Italia (Milan, I964); Riosa, Il sindacalismo rivoluzionario; C. Cavallari, Classi dirigenti e minoranze rivoluzionarie. Il protomarxismo italiano: Arturo Labriola, Enrico Leone, Cesare Longobardi (Naples, 1983); Favilli, Storia del marxismo italiano.

I5. We have only one full-length biography of Enrico Leone, but he too could be afforded another monograph; see W. Gianinazzi, L’itinerario di Enrico Leone (Milan, 1989). For his ideas see works referred to in footnote I4, and E. Zagaria, Marxismo e revisionismo: Bernstein Sorel Graziadei Leone (Naples, 1975); P. Favilli, Riformismo e sindacalismo (Milan, 1983). 
locally-based chambers of labour and in particular greater control of the strike weapon during industrial bargaining. ${ }^{16}$ After $1906-1908$, a second phase in the history of Italian syndicalism opens. Much of the most interesting work on Italian syndicalism written since the I970s centres on this "second" generation of Italian syndicalists. Although there is no single monograph devoted to a prosopographical study of this "generation", a synthesis of extant biographies allows us to draw a bigger picture. ${ }^{17}$

A younger generation of labour organizers, in many ways sociologically different from the "professors", became particularly active in the Po Valley. This group of lower-middle-class lawyers, white-collar workers, teachers and journalists shifted the emphasis of labour organizing from the industrial areas of the northern triangle to the commercialized agricultural areas of the Po Valley. Syndicalists were successful in organizing in those provinces where the more reformist Federterra (agricultural workers' union close to the PSI) was prevented from doing so due to employer resistance. Thus if the first generation of syndicalists had concentrated their efforts on winning the northern urban working class, their successors, in a series of spectacular agricultural general strikes (Parma 1907, Ferrara 1908), achieved initial success in a different setting. ${ }^{18}$ Success was due to a shrewd policy of combining militant opposition to employers with alliance building across rural social classes. These organizers included sharecroppers in the wider struggles of the landless labourers. However, after their initial success, they threw caution to the winds and launched a new cycle of demands that antagonized allies and enemies alike. The agrarian employers organized effective strikebreaking

16. For the foundation of the CGL and the syndicalists, see Riosa, Il sindacalismo rivoluzionario, pp. 331-82; I. Barbadoro, Il sindacato in Italia (Milan, 1979), pp. 339-49o. For FIOM see M. Antonioli, Sindacato e progresso: la Fiom tra immagine e realtà (I90I-I9I4) (Milan, I983).

17. Biographical and sociological details of the "second generation" can be gathered from Bertrand, "Revolutionary Syndicalism", pp. 28-74; Riosa, "Il sindacalismo rivoluzionario", pp. 33I-382; A. Riosa, "Il sindacalismo rivoluzionario in Italia dal 1907 alla 'Settimana Rossa", Movimento operaio e socialista, second series, 3 (I979), pp. 5I-87; T. Sykes, "The Practice of Revolutionary Syndicalism in Italy 1905-19II" (Ph.D., Columbia University, 1973); entries in F. Andreucci and T. Detti (eds), Il movimento operaio italiano. Dizionario biografico, vols I-5 (Rome. 19751978); entries by myself in A. Thomas Lane (editor-in-chief), Biographical Dictionary of European Labor Leaders, vols I and 2 (Westport, CT, 1995). For an interesting first attempt at a prosopographical account of the "first" generation of Italian syndicalists, see W. Gianinazzi, "Agli albori del sindacalismo rivoluzionario italiano. Genesi di una generazione intellettuale", Rivista storica dell'anarchismo, 3 (1996), pp. 5-I4.

18. These strikes have been covered in great detail, see A. Roveri, Dal sindacalismo al fascismo. Capitalismo agrario e socialismo nel ferrarese (Florence, I972); U. Sereni, "Alleanze e obbiettivi intermedi nell'azione della camera del lavoro di Parma”, Ricerche storiche, 5 (1975), pp. I29-I46; U. Sereni, Camera del Lavoro, Agraria e ceti medi a Parma nell'età giolittiana (Parma, 1975); idem, Processo ai sindacalisti parmensi (Lucca, I978); G. Reggiani, "Per una storia del sindacalismo rivoluzionario nel parmense durante l'età giolittiana”, Ricerche storiche, 5 (1975), pp. 23-44; T. Sykes, "Revolutionary Syndicalism in the Italian Labour Movement: The Agrarian Strike of 190708 in the Province of Parma", International Review of Social History, 2I (I976), pp. I86-2II. 
organizations and syndicalists alienated Catholic sharecroppers by emphasizing a strategy that would have led to their proletarianization. The defeats in Parma and Ferrara coupled with the growing national prestige of the CGL, eroded syndicalist strength. After 1908 the movement was riven by dissent and failed to gain new adherents outside a rump of Chambers of Labour located in agricultural areas. After defeats in Parma and Ferrara many of the leading syndicalists advocated entry into the CGL, whilst others became independent candidates for Parliament. ${ }^{19}$

To confuse matters further, some syndicalist intellectuals, who had little to do with labour organizing in the Po Valley, embraced Sorelianism and the elitist theories of Mosca and Pareto, and provided ideological assistance to the new Nationalist Association. ${ }^{20}$ Although these individuals were largely extraneous from working-class organizations and popular culture, their concept of a "proletarian" Italy, a new corporate society of aggressive entrepreneurs and productive, disciplined workers harnessed together in a quest for imperial conquest, foreshadowed the fascist synthesis. In a more direct manner, however, the Nationalist Association helped foster a new, more militant generation of employers' federations.

A third phase in syndicalism's history can be linked to the more militant stance adopted by these employers' federations. ${ }^{21}$ Giolitti veered to the right during the Libyan War in I9II-I9I2 and sought to build a coalition of the nationalist and Catholic middle classes. Concurrently, he expanded the suffrage to virtually all males over the age of twenty-five. The Libyan War destabilized labour markets and led to inflation and unemployment that undermined the modern sectors of the economy. Syndicalism shifted back to industrial Italy. In I9IO and I9II a series of bitter strikes in the iron and steel company towns of Piombino and Terni in central Italy foreshadowed a cycle of massive industrial disputes in Milan and Turin during I9II1913. ${ }^{22}$ Now syndicalist organizers made remarkable advances in the most

19. The best account is still Riosa's, see "Il sindacalismo rivoluzionario in Italia dal I9O7 alla 'Settimana Rossa'”.

20. On the syndicalist origins of Italian nationalism, see A.J De Grand, The Italian Nationalist Association and the Rise of Fascism (Omaha, NB, 1978); Roberts, The Syndicalist Tradition; Z. Sternhell with M. Snzajder and M. Asheri, The Birth of Fascist Ideology from Cultural Rebellion to Political Radicalism (Princeton, NJ, 1995).

2I. The new militancy of employers is examined in R. Webster, Industrial Imperialism in Italy, I908-19I5 (Berkeley, CA, I975); A. Pepe, Lotta di classe e crisi industriale. La svolta del I9r3 (Milan, 1978).

22. M. Degl'Innocenti, "Il sindacalismo rivoluzionario e la crisi del giolittianismo", Ricerche storiche, 5 (1975), pp. 98-108. The most detailed account of the general strikes in Milan is L. Gestri, "I9I3: l'USI e lo sciopero generale", Ricerche storiche, 6 (I976), pp. 3-86. For Turin, see Levy, Gramsci and the Anarchists, ch. 2. Sereni notes the return of the defeated Parma syndicalists to prominence after I9I0. See U. Sereni, "Il I9ı0: un anno cruciale per il sindacalismo rivoluzionario italiano", Annali dell'Isituto di Storia della Facoltà di Magistero dell'Università di Firenze, 3 (1982I984), pp. 83-108. 


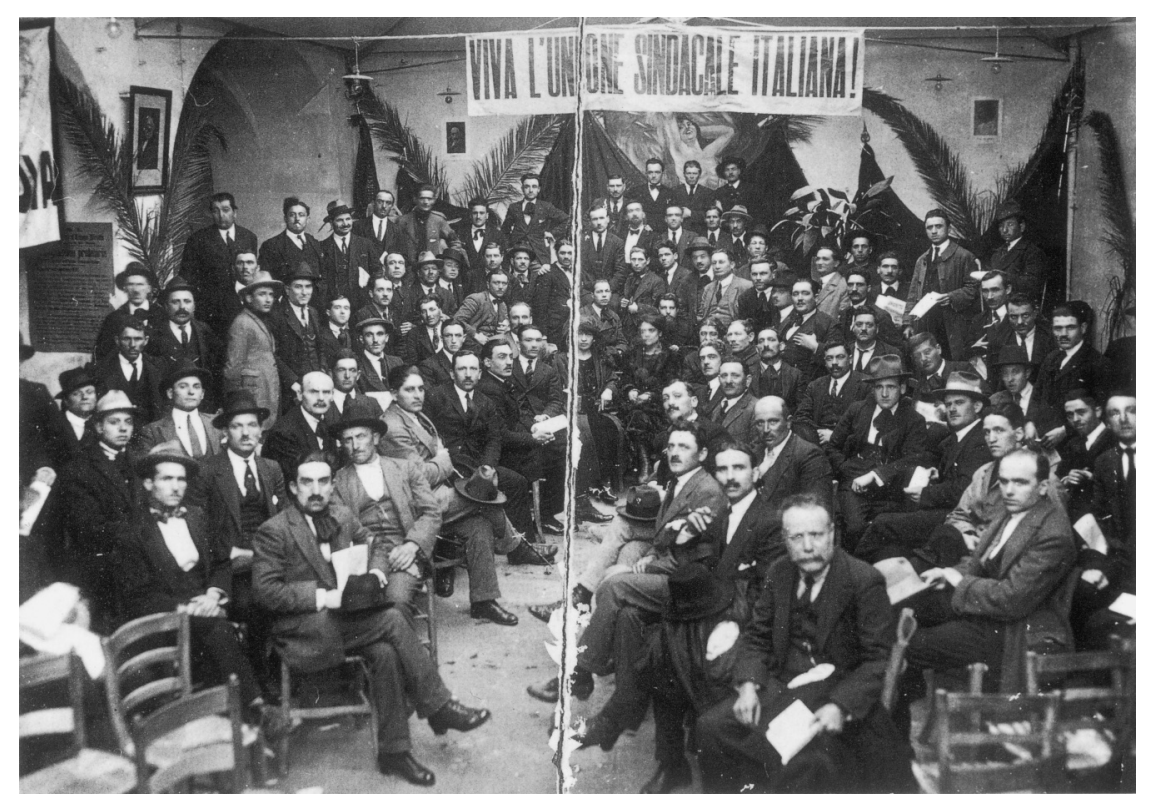

Figure 2. The Central Committee of the Unione Sindacale Italiana meets for the first time, Bologna, I5-I7 December 1912. The USI had been founded a few weeks earlier in Modena and confirmed the split of the Italian socialist trade union movement into revolutionary and reformist wings.

CGIL: Il lavoro della Confederazione (Milan, I988), p. 4 I.

industrialized areas of Italy. Success for the newly-established Unione Sindacale was due to the combined effects of the weakness of the CGL in the face of an employers' offensive and the meshing of older libertarian/anarchist working-class traditions largely maintained in the camere del lavoro, rather than to permanent support for the USI by the working classes in Milan or Turin.

The USI was founded in I9I2 based on an alliance of the older agricultural chambers of labour and a new stratum of dynamic industrial organizers. ${ }^{23}$ By I9I3, the USI had a membership half the size of the CGL, but the latter's numerical superiority depended on the big battalions of the agricultural workers' Federterra. In industrial areas the contest was much closer, and in some areas (particularly in Milan), members of the CGL went over en masse to the USI. ${ }^{24}$ However, like previous syndicalist organizations, the

23. The most detailed account of the origins of the USI is U. Sereni's "Da Langheranno a Modena: la costituzione dell'Unione Sindacale", Movimento operaio e socialista, I8 (1975), pp. 279309.

24. In I9I3 the USI's metalworking and engineering union counted 14,243 members while FIOM had 10,636 members. Figures are derived from Gestri, "I9I3: L’USI e lo sciopero generale”, p. I5, and Degl'Innocenti, "Il sindacalismo rivoluzionario", p. IO4. 
USI remained an inherently unstable organization. The major dispute centred on the rift between the largely agricultural Chambers of Labour and the industrial organizers spearheaded by Filippo Corridoni. ${ }^{25}$ While the industrial unionists wanted greater centralization based upon a system of industrial unions, the cameralists envisaged the USI as little more than a confederation of Chambers of Labour.

The cycle of growing industrial militancy peaked with the Red Week of early June 19I4. This protest/insurrection was the product of antimilitarist campaigning in the wake of the Libyan War organized by a coalition of republicans, radical socialists led by Mussolini, the USI and, most importantly, a rejuvenated anarchist movement under the charismatic leadership of Errico Malatesta.

This campaign became very popular in northern and central Italy. Here the army was disliked because of its use by Crispi in the I89os, and the memories of the mass shootings in Milan in 1898, the near dictatorship of General Pelloux and the many "proletarian massacres" that marred the more cordial era of Giolittian industrial relations from I9OI to I9I4. However, after a week in which parts of central Italy established mini-republics, the movement collapsed and leaders were either jailed or fled the country. This disillusioned many syndicalist leaders with the strategy of pure direct action. They now advocated a drive to win communal elections.

In what manner this syndicalist version of municipal socialism would have differed from prewar reformist or postwar maximalist socialist municipal socialism is hard to say, and academic in any case because the great debate over the intervention of Italy in the First World War split the USI. ${ }^{26}$

25. Maurizio Antonioli has written extensively on Corridoni; see his "Sindacalismo rivoluzionario italiano e modello industrialista da Filippo Corridoni ai sindacati nazionali d'industria (I9II1914)", Ricerche storiche, 5 (1976). pp. I4-78; and "L'attività sindacale di Filippo Corridoni", in idem, Azione diretta e organizzazione operaia. Sindacalismo rivoluzionario e anarchismo tra la fine dell'Ottocento al il fascismo (Manduria, 1990), pp. 265-302. Also see, L. Salsiccia, Filippo Corridoni. Una vita per la rivoluzione (Corridonia, 1987) and M.B. Sentieri (ed.), Filippo Corridoni. Mito e storia dell" "Archangelo Sindacalista" (Rome, 1988).

26. The best accounts of the Red Week are found in L. Lotti, La settimana rossa (Florence, 1972) and the more recent and informative M. Murtaugh, Italian Labor in Protest, 1904-19I4 (New York, I99I). Inefficient and often brutal law enforcement during industrial disputes in the Giolittian era added credence to direct actionist and antistatist ideologies on the left. The forces of law and order were understaffed and relied on militarized techniques that inevitably led to a cycle of deaths, demonstrations and more strikes. For the legal and policy contexts, see G. Neppi-Modona, Sciopero, potere politico e magistratura, I870-I922 (Bari, I972); R. Canosa and A. Santusuosso, Magistrati, anarchici and socialisti alla fine dell'Ottocento in Italia (Milan, 1981); J.A. Davis, Conflict and Control: Law and Order in 19th Century Italy (Basingstoke, 1988), pp. 217-237; R.B. Jensen, Liberty and Order: The Theory and Practice of Italian Public Security Policy: 1848 to the Crisis of the I8gos (New York, I99I); J. Dunnage, "Law and Order in Giolittian Italy: A Case Study of the Province of Bologna", European History Quarterly, 25 (1995), pp. 38I-400; idem, The Italian Police and the Rise of Fascism: A Case Study of the Province of Bologna, I897-I925 (Westport, CT, 1995); A. J. De Grand, "Giolitti and the Socialists", in S. M. Di Scala (ed.), Italian Socialism Between 
Between the summer of 1914 and early 1916 the USI was consumed by debate over Italy's entry into the war, and once this happened in May 19I5, over the proper attitude of the USI towards collaboration with the state during the war. ${ }^{27}$ Many of the first interventionists were republicans, anarchists and syndicalists who had protested against the Italian monarchy in June I9I4.

The distinctive importance of republican and Mazzinian ideology in the formation of Italian syndicalism came into play at this moment. These traditions were assimilated into the rhetoric of a radical populist interventionism. Once again French ideological and cultural assumptions were extremely important for the Italian syndicalists and like the prewar critique of "German Marxism" by French syndicalists, the Italians' rhetoric displayed the potential for support for a future patriotic war even before I9I4. The Second International had been dismissed by certain Italian syndicalists as an organization dominated by "Teutonic" bureaucratic Marxism. Furthermore, the syndicalists, along with many socialists, had inherited the tradition of the nation-in-arms embodied in Garibaldi's exploits. On the one hand was the top-down establishment imperialism carried out in Eritrea, Abyssinia or Libya, which led to the downfall of Crispi in 1896 or the crisis of Giolittianism after I9II; on the other were just people's wars of oppressed nationalities, such as when socialists and anarchists had joined Mazzinians to fight with Cretan rebels against their Turkish overlords in I897. Thus a republican and syndicalist reading of war aims in 1915 presented intervention as the Fourth War of the Risorgimento; a war in which popular mobilization would force the Italian monarchy to fight the Habsburgs to liberate Italians beyond Italy's northeastern frontiers. ${ }^{28}$ The after effects of the Red Week helped prevent Italy from entering on the side of the Triple Alliance. As we have seen, the Red Week had grown out of an antimilitarist and antimonarchist campaign. Entry on the side of the Habsburgs would have

Politics and History (Amherst, MA, 1996), pp. 23-37; G. Sacchetti, "Controllo sociale e domicilio coatto nell'Italia crispina”, Rivista storica dell'anarchismo, 2 (1995), pp. 5-27.

27. For the war interventionist debate within the USI, see O. Luppo, "I sindacalisti rivoluzionari nel I9I4", Rivista storica del socialismo, IO, 32 (I967), pp. 43-82; C.L. Bertrand, "Italian Revolutionary Syndicalism and the Crisis of Interventionism", Canadian Journal of History, Io (1976), pp. 346-367; U. Sereni, "Luglio-Agosto I9I4: alle origini dell'interventismo rivoluzionario", Ricerche storiche, II (198I), pp. 525-574. The debate after the entry of Italy into the war in May I9I5 and the resulting schism between USI and UIL is dealt with by Bertrand, "Revolutionary Syndicalism in Italy", pp. I46-I48 and M. Antonioli, Armando Borghi e l'Unione Sindacale Italiano (Manduria, 1990), pp. 24-32.

28. I cover the ambiguous attitudes of the socialist and libertarian Italian left before I9I5 towards patriotism and legitimate wars of national defence; see C. Levy, "The Italian Socialist Party and the Second International", Labour History Review, 58 (I993), pp. I8-25. Also see the specific analysis of the prewar syndicalists by P. Favilli, "Il sindacalismo rivoluzionario italiano (I905-I9II) e la 'dimensione del guardar fuori'. Una politica estera?", Ricerche storiche, IO (198I), pp. 240-279. For a general discussion of the antimilitarism in the Italian left before 1915 , see G. Oliva, Esercito, paese e movimento operaio. L'antimilitarismo dall'I86I all'età giolittiana (Milan, I986). 
seen the renewed mobilization of this "subversive left" against the monarchy. Indeed, until the Western Front stabilized after the First Battle of the Marne in the early autumn of 1914, the old anarchist and Garibaldinian based in Paris, Amilcare Cipriani, had led a rather successful syndicalist-inspired campaign to recruit volunteers to fight for France, just as his Risorgimento generation of republicans and radicals had fought for the French Republic in $1870-1871 .{ }^{29}$

There were also certainly other more irrational voices, especially amongst the older generations of syndicalists who had grown closer to nationalism or had left the movement in a fit of colonialist pique during the Libyan War. These groups of publicists were close to the futurist praise for the "hygienic qualities" of war, but their real influence was exaggerated by their control of printing presses or outlets for their publications, and this exaggeration of influence has been continued in some studies of Italian syndicalism that have been seduced by flowery literature, but have failed to question who actually read it. ${ }^{30}$

Within the USI, the interventionist debate led to the loss of its two most important bases: the industrialist Unione Sindacale Milanese and the agricultural chamber of labour in Parma. However, the remaining cameralists of the Po Valley and Apulia, as well as a nucleus of Ligurian industrial unionists in Genoa's industrial hinterland remained within the antiwar internationalist USI. Membership shrank from over I0o,000 to less than 50,000. ${ }^{3 \mathrm{I}}$ However, after the Armistice, the USI was again threatening the CGL. Under the leadership of the anarchist journalist Armando Borghi, during the war a group of anarchists and direct actionist syndicalists became the dominant force within the USI and retained this dominance in the biennio rosso.

This historical overview of syndicalism up to the end of the Great War can be summarized in the following manner. Starting off as a faction within the Socialist Party, syndicalism splintered into a kaleidoscope of local movements, found new unity in the prewar direct action USI, and during and

29. The debate over war interventionism amongst anarchists and syndicalists in I9I4 and I9I5 is discussed by P.C. Masini, "Anarchici italiani tra interventismo e disfattismo rivoluzionario", Rivista storica del socialismo, 5 (1959), pp. 208-212 and G. Cerrito, L'antimilitarismo anarchico in Italia nel primo ventennio del secolo (Pistoia, I968). More recently published letters between interventionist and anti-interventionist libertarians are analysed by Maurizio Antonioli: see "Gli anarchici italiani e la prima guerra mondiale. Lettere di Luigi Fabbri e di Cesare Agostinelli a Nella Giacomelli (I9I4-I5)", Rivista storica dell'anarchismo, I (I994), pp. 7-34; idem, "Gli anarchici italiani e la prima guerra mondiale. Lettere di anarchici interventisti (I9I4-I5)”, Rivista storica dell' anarchismo, 2 (I995), pp. 77-87. See also S.P. Whitaker, "Leandro Arpinati anarcosindacalista, fascista, fascista pentito", Italia contemporanea, I96 (I994), pp. 47I-489.

30. For the futurists, see Berghaus, Futurism and Politics, pp. 73-83.

3I. See the estimates of membership in M. Antonioli and B. Bezza, "Alcune linee interpretive per una storia dell'Unione Sindacale Italiana. Un inedito di Armando Borghi”, Primo maggio, I (I973), pp. 57-65. 
after the war became more openly dominated by committed anarchists. Syndicalist labour organizing began in the industrial north and amongst miners and quarrymen in Tuscany, shifted with some initial success to the agricultural Po Valley (and slightly later, agricultural Apulia), and just before the outbreak of war shifted again to the most modern industrial sectors in the urban north, scoring short-lived if rather remarkable successes. Through its long-standing attachment to the French republican revolutionary tradition and home-grown Mazzinian republicanism, syndicalism as an ideology attracted elements of the educated middle class who were dissatisfied with the "Giolittian" monarchy and were edging towards populist nationalism. Indeed, as we shall see, Italian syndicalism acted as a field of force for an unstable ensemble of different social classes and individuals who shared a deep alienation from liberal Italy.

However, merely tracing the fortunes of syndicalism within the PSI and the USI would be misleading, as it affected politics and political discussion outside labour movements. Indeed one of the greatest problems confronting the historiography of Italian syndicalism is the lack of careful analysis of both its working- and populist middle-class "souls". But even within the history of the labour movement the wider syndicalist impulse has been ignored or not successfully integrated into more general accounts of industrial relations during the Giolittian era. Either it has been pigeonholed in studies interested in the origins of fascism or hidden away in discrete accounts of individual trade unions. While these may be disparate impulses and movements, nevertheless they all shared ambitions to make the Italian left less Marxist and more labourist; a labourism, however, which was considered in different contexts more moderate or radical than the practice of the trade unions associated with the CGL.

The railway workers' union (SFI, Sindacato Ferrovieri Italiano), certainly had a syndicalist element in its organization. ${ }^{32}$ The union was only really effective in the north amongst certain grades of workers and faced competition from Catholics. It was split between syndicalist, socialist and anarchist factions. An anarchist leadership kept the union from splintering, but its main aim was to defend the right of railway workers to strike and reinstate sacked workers who had gone on strike. From 1907 until the biennio rosso it carried on syndicalist-type strategies but never affiliated to a syndicalist organization. Although it promoted direct action, it was also prepared to use socialist parliamentarians and parliamentary commissions to advance the cause of railway workers.

In this respect it was in a rather similar position to the seafarers' union (FLM, Federazione Lavoratori del Mare); ${ }^{33}$ albeit the union's colourful

32. M. Antonioli, R. Bernardi and G. Checcozzo (eds), Il Sindacato Ferrovieri Italiano dalle origini al fascismo, 1907-25 (Milan, 1994).

33. G. Dinucci, Una federazione tra riformisno e sindacalismo: La Federazione Nazionale Lavoratori del Mare I90I-I908 (Florence, 1983). 
leader, Captain Giovanni Giulietti, ${ }^{34}$ was further to the right than the anarchist and syndicalist leadership of the SFI. Giulietti certainly used syndicalist strategies to help control the labour market. By organizing "deckhands to captains", the FLM adopted a form of industrialism, and prevented the splintering of seafarers' representation into a myriad of craft-based organizations, utilizing similar methods to those employed by the SFI organizers on the railways. Giulietti was a practitioner of both direct action (spectacular strikes before the war) and parliamentary influence-peddling. The wealth of the seafarers' cooperative and his nationalist populism during the war allowed Giulietti to straddle the interventionist/anti-interventionist divide after the war. As a Mazzinian radical he endorsed D'Annunzio's seizure of Fiume in I919, and supplied him with arms from a hijacked ship, but he also smuggled Malatesta back from England at the end of December I919. Indeed, he was central to the bizarre but aborted plans for a "March on Rome" in January 1920 involving the anarchists, the USI, D'Annunzio and his legionnaires, the SFI and the maximalist socialists. ${ }^{35}$

Giulietti's populist Mazzinian syndicalist politics was very close to that of the prowar syndicalists within the USI who created the UIL during the First World War. The Italian Union of Labour is sometimes equated with the rise of fascist labour organizations in the early 1920s. ${ }^{36}$ In fact many of these syndicalists envisaged the First World War as a democratic and republican crusade. Although Corridoni, the industrial syndicalist organizer, died on the Carso and became a fascist secular saint, ${ }^{37}$ other syndicalist interventionists such as Giuseppe Di Vittorio, a young Apulian organizer of landless labourers, became communists. In any case, many of the members of the UIL should probably be termed populists rather than fascists. Indeed, many of them rejoined the anti-interventionist left in the postwar era and the so-called corridoniani were significant in the successful defence of Parma's working class districts against fascist assault in $1922 . .^{38}$ On the other

34. G. Salotti, Giuseppe Giulietti (Rome, 1982). For a taste of his bizarre mind, see Giulietti's memoirs, Pax Mundi (Naples, 1945).

35. I summarize the extensive literature on Giulietti's role in the events of January I920 in C. Levy, "Charisma and Social Movements: Errico Malatesta and Italian Anarchism", Modern Italy, 3 (I998), p. 210.

36. For a balanced account of the UIL, see Bertrand, "Revolutionary Syndicalism in Italy", pp. I47-I52. Also see F. Cordova, Le origini dei sindacati fascisti (Bari, 1974).

37. For a fascist hagiography of Corridoni, see I. De Begnac, L'Arcangelo sindacalista. Filippo Corridoni (Verona, 1943). For an analysis of this operation, see A. Riosa, "I miti del fascismo e le tante anime dell'apostolo Filippo Corridoni", Ricerche storiche, I2 (I983). A communist historian's account of Di Vittorio's early career that does not censor his interventionism is Michele Pistillo's Giuseppe Di Vittorio 1907-I924 (Rome, 1973). For the connections between syndicalism and communism in Apulia, see L. Allegato, Sindacalismo rivoluzionario e comunismo in Puglia (Manduria, 1988).

38. B. Casonato, "Agli inizi del fascismo parmense", in L. Casali (ed.), Movimento operaio e fascismo nell'Emilia Romagna I9I9-1923 (Rome, I973), pp. 293-324; G. Falotti, "Parma: le barricate dell'22", Rivista storica dell'anarchismo, 2 (I995), pp. 77-IO2; Berghaus, Futurism and Politics, pp. I72-I80. 


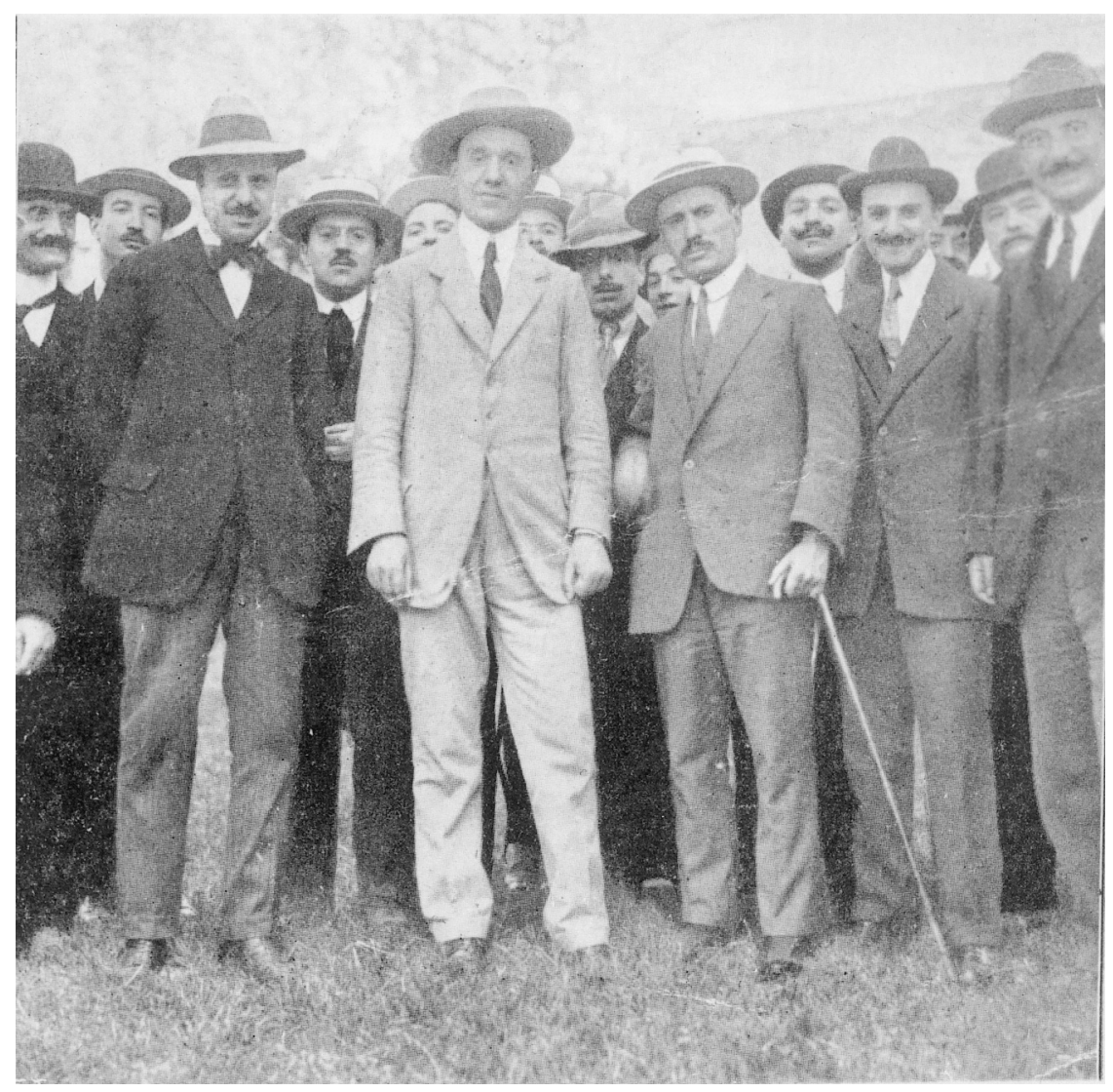

Figure 3. Filippo Corridoni (centre) with Benito Mussolini (centre right) and Alceste de Ambris (left) in the Milan Arena, May 1915, after a rally favouring Italy's participation in World War I. Corridoni (I887-1915) was a founding member of the Unione Sindacale Italiana, and animated the Red Week in Milan 19I4. A few months after this photograph was taken he died at the Carso front. The fascists later honoured him as a hero of the fatherland.

International Institute of Social History, Amsterdam

hand, syndicalists such as Edmondo Rossoni, were instrumental in the creation of fascist counterparts which filled the void after the destruction of socialist and syndicalist peasant leagues in the Po Valley in I92I-I922. Historians who merely see the UIL as a prelude to fascist labour organizations simplify a complicated story.

The interventionists and the fascists of "the first hour" argued that overly ideological Marxist internationalism distorted the important and legitimate vocation of the free labour syndicate. Another type of reformist syndicalism, with some of the same assumptions about the nefarious effects of Marxist intellectuals, spread into the heart of the CGL itself. Although there has 
been one pioneering study, the role of reformist syndicalism within the CGL and its affiliate unions deserves much greater study. Rinaldo Rigola, secretary of the CGL, dabbled with "labourism" before the war. In other words, the CGL would replace the notables of the PSI as the representative of the Italian working class, and Rigola's attempts were supported theoretically by at least two syndicalist thinkers of some originality, Antonio Graziadei and Ernesto Longobardi. ${ }^{39}$ But this attempt at creating an Italian Labour Party was stymied by the opposition of Federterra which relied upon socialist parliamentary deputies winning work contracts for their cooperatives during the dead season when the landless labourers faced unemployment and destitution. Furthermore, other leading trade unionists, such as Bruno Buozzi, the secretary of FIOM, who adopted certain practices from industrial unionism and praised the French syndicalist leader of the metallos, Alfonse Merrheim, still refused to leave the PSI because he felt threatened by the USI and saw the merit of parliamentary pressure in Rome. ${ }^{40}$

Thus the influence of syndicalism was not merely connected to the family tree associated with the USI, but it can be also noticed in a broader if nebulous discourse and in the practice of the Italian labour movement before I9I4.

\section{THE SOCIOLOGY OF ITALIAN SYNDICALISM}

The sociology of Italian syndicalism has been a very contentious field of study. Thanks to the popularity of Antonio Gramsci's interpretation of the Southern Question, historians within and without the communist tradition have approached the study of Italian syndicalism with misleading first assumptions. Gramsci believed that "syndicalism (was) a weak attempt on the part of the southern peasants represented by their most advanced intellectuals, to lead the proletariat".$^{4 \mathrm{I}}$ Italian syndicalism, according to Gramsci, was a popular vehicle through which southern concerns - the limitation of emigration, free trade, the exploitation of the south by the Giolittian political system and the monarchy - could become popularized in the north and thus break the corporate, inward-looking nature of the northern working class. These were the beneficial aspects of syndicalism; its deleterious effects were explained using sociological arguments. Since the intellectuals of syndi-

39. C. Cartiglia, Rinaldo Rigola e il sindacalismo riformista in Italia (Milan, 1978). For the intellectuals, see P. Favilli, Riformismo e sindacalismo; idem, "Marxismo e sindacalismo rivoluzionario in Italia", Società e storia, 46 (1994), pp. 64-65; idem, Storia del marxismo italiano. In general, see A. Pepe, "Il socialismo italiano e il rinnovamento del capitalismo (I900-I922)", Studi storici, 33 (I992), pp. 353-365. For Merrheim's reformist syndicalism, see N. Papayanis, Alphonse Merrheim: the Emergence of Reformism in Revolutionary Syndicalism, I87I-I925 (Boston, MA, 1985).

40. Levy, Gramsci and the Anarchists, p. I3I.

4I. A. Gramsci, Selections from Political Writings (I92I-I926), (translated and edited by J. Mathews

(London, 1978), p. 450. 
calism were rural southerners, it was ultimately a retrograde doctrine, indeed, more backward than most varieties of Second and Third Internationalist Marxism.

The importance of this intervention for the evolution of Gramsci's conception of hegemony cannot be overestimated. Syndicalism and "southernism" (meridionalismo) were used as prime examples of failed forms of hegemony in which key concepts such as "organic intellectuals" and "traditional intellectuals" and "senso buono" and "senso comune" were employed to explain how southern intellectuals retarded the modernization of Italy and prevented a socialist revolution. ${ }^{42}$

Although Gramsci's intervention against syndicalism and meridionalismo can tell us a great deal about the intellectual origins of his unique Marxism, there are several empirical weaknesses in Gramsci's specific arguments concerning the history and nature of Italian syndicalism.

First, he fails to detect the grapevine which underpinned the solidarity of northern workers with southern peasants, certainly from the I89os and therefore before syndicalism as an "ism" even existed. Secondly, Gramsci does not acknowledge that his own idea of a producers' society linked to the factory council movement owed its popularity during the biennio rosso not to the fact that the metalworkers of Turin shared his interesting, if eclectic readings of Georges Sorel, Antonio Labriola, Giovanni Gentile and Benedetto Croce. Rather, thanks to their socialization within a prewar popular culture dominated by libertarian and anarchist texts and cultural symbols, as well as the twin influences of anarchists and syndicalists active in the FIOM and the USI, the concepts of workers' councils and workers' control were easily comprehended. Indeed, Gramsci's own syndicalist-like early Marxism was to some degree directly affected by a critical, if not totally dismissive, reading of the theoretical work of the first generation of Italian syndicalists, his direct acquaintance with Sardinian populist-cum-syndicalist figures such as Attilio Defenu, and, perhaps most importantly, a consistent fascination with certain aspects of Georges Sorel's work. ${ }^{43}$ It is impossible to understand Gramsci's productivist council communism during the biennio rosso without reference to Sorel, and the French thinker readily acknowledged his affinity with Gramsci's interventions in Turin. ${ }^{44}$

42. A very good, recent account of Gramsci's concept of hegemony is found in James Martin's Gramsci's Political Analysis: A Critical Introduction (Basingstoke, 1998). Nadia Urbinati notes the importance of Gramsci's writings on the Southern Question for the formulation of his conception of hegemony. See N. Urbinati, "The Souths of Antonio Gramsci and the Concept of Hegemony", in J. Schneider (ed.), Italy's "Southern Question" and the Concept of Hegemony: Orientalism in One Country (Oxford, 1998), pp. 135-156.

43. I deal with the early Gramsci and syndicalism in my Gramsci and the Anarchists, pp. II-I3; 63-64.

44. Ibid., chs 3-5; M. Malatesta, "Gramsci e il sindacalismo rivoluzionario. Riflessioni sul rapporto tra analisi storiografica e giudizio di valore”, Ricerche storiche, Io (198I), pp. 327-357; F. Soldoni, La struttura del dominio nel sindacalismo rivoluzionario e nel giovane Gramsci (Milan, 1985); 
Thirdly, a prosopographical analysis of the leading figures in prewar Italian syndicalism has demonstrated that the numbers of leaders and intellectuals from the south (approximately one-third), was roughly proportional to the contemporaneous population of Italy. Furthermore, the federalism and antistatism which Gramsci associated with the southerners could also be found in the writing and speeches of northerners. It is misleading for Gramsci to reduce syndicalist intellectuals to mere spokespersons for the interests of southern peasants. Indeed southern syndicalist intellectuals of the "first generation" uncritically embraced the modernity of the industrial north and their first base was Milan. For them the salvation of Italy lay in the modernization process pioneered in the north. It is best to recall that the "first generation" of Italian syndicalists were largely ignorant and even hostile to the problems of rural Italy.45

The limitations of Gramsci's approach should not obscure the important contributions to the emergence of a more nuanced investigation of the social roots of Italian syndicalism during the I970s and I980s by Italian communist historians raised in the Gramscian tradition. Indeed, at three key conferences in the 1970s (Piombino, 1974, Ferrara, I977 and Carrara, 1978), communist historians demonstrated an admirable empiricism which implicitly undermined many of Gramsci's and their own first assumptions. ${ }^{46}$

It is now possible to give a more accurate picture of the sociology of Italian syndicalism using the last twenty years of detailed empirical study. As a social movement, syndicalism lived in symbiosis with anarchist and socialist political cultures. Syndicalism thrived in a broader libertariantinged "second culture", of which I have written about at length elsewhere. This can be summarized as a bundle of cultural practices and organizational activities associated with localism, antistatism, anticlericalism, republicanism and operaismo (workerism). The denizens of the "second culture" were selfeducated artisans and skilled workers with a political education grounded

D. Schecter, Gramsci and the Theory of Industrial Democracy (Aldershot, I99I); M. Martelli, "Gramsci e la democrazia consiliare", in R. Giacomini, D. Losurdo and M. Martelli (eds), Gramsci e l'Italia. Atti del convegno internazionale di Urbino, 24-25 gennaio 1992 (Naples, 1994), pp. 339-349. Darrow Schecter has written a very interesting account of the Gramsci/Sorel relationship, but he detects a greater distance between the two in 1919-1920 than I do. See D. Schecter, "Two Views of the Revolution: Gramsci and Sorel, 1916-I920", History of European Ideas, I2 (1990), pp. 636653.

45. For a sociology of the Italian syndicalist intellectuals see G.B. Furiozzi, "Il meridionalismo dei sindacalisti rivoluzionari", in Cingari and Fedele, Il socialismo, pp. I54-I7I. David Roberts (The Syndicalist Tradition, p. 56) explains the complex relationship between southern syndicalist intellectuals and northern modernity. He concludes that syndicalists wanted "healthy, new industrial classes who could redeem Italy, not decrepit pre-industrial classes of the South".

46. The participants' papers to the Piombino and Ferrara conferences were published respectively in Ricerche storiche ( 5 of 1975 , and I of $198 \mathrm{I}$ ). The Carrara conference is found in M. Bertozzi (ed.), Sindacalismo rivoluzionario: quale approccio storiografico? (Pisa, 1980). Guerrazzi gives a very good summary of the arguments in "Il sindacalismo rivoluzionario in Italia". 
in anarchist and republican literature. Marx and Engels were known as famous socialist thinkers but other sources and examples shaped their views. The poetry of the positivist sociologist and vagabond Pietro Gori, the pamphlets and "moral dialogues" of Errico Malatesta, thousands of unrecorded anticlerical speeches by stump orators or the historical example of the Paris Commune and the exploits of Garibaldi and the garibaldini were far more important than the theory and practice of the socialism of the Second International. The Italian state called them sovversivi and they wore this badge with honour. The social distance between the professors, who were the public face of the Italian Socialist Party, and these "subversives" was immense. The geographical seedbed for this culture stretched from Tuscany to Emilia-Romagna and on to the Marches. In the early twentieth century migration of Tuscans or Romagnoles to the industrial north brought this culture to the industrial triangle of Milan, Turin and Genoa. Industrial modernization did not undermine this vibrant culture before $1915 .{ }^{47}$

Equally important, however, were "political opportunity structures" that facilitated the persistence of this "second culture". The Italian Socialist Party left much room for syndicalism to prosper. The PSI evolved from an umbrella of regional associations to a single-member-based party, which officially stressed its opposition to anarchism and endorsed Marxist socialism and the organizational model of the SPD. Membership expanded from 27,000 in I897 to 37,000 in I9I3. Meanwhile, its electoral strength in national polls grew as manhood suffrage expanded from eight per cent to near universal manhood suffrage in I9I3. The socialists captured nine per cent of the vote in 1897 and seventeen per cent in 1913. Nevertheless, the PSI before I9I4 never exercised the same control over the left as the SPD did in Germany. The chief institutions of the party included the GPS (the socialist parliamentary group), Avanti! (the national party newspaper), the national directorate and the local sections. But unlike the Germans, the Italian party never created massive national organizations, nor did the previously mentioned organizations behave in a disciplined fashion or possess particularly strong finances. ${ }^{48}$

47. I first advanced the concept of the "second culture" in "Italian Anarchism, I870-I926", in D. Goodway (ed.), For Anarchism: History, Theory and Practice (London, 1989), pp. 24-78. I gave detailed examples of the transmission of this culture from its seedbeds in north central Italy to Turin; see Levy, Gramsci and the Anarchists, pp. 19-2I, 34-43, 46-52. For the Milanese case, see D.A. Bell, Sesto San Giovanni: Workers, Culture and Politics in an Italian Town, 1880-1922 (New Brunswick, NJ, 1986). For an analysis of the political culture of these "seedbeds" see T. Detti, "Ipotesi sulle orgini di una provincia rossa: Siena tra Ottocento e Novecento", Ventesimo secolo, 2 (I99I), pp. 49-62, and M. Degl'Innocenti, La società unificata. Associazione, sindacato, partito sotto il fascismo (Manduria, 1995), pp. 8-II. Sharif Gemie has employed the concept of a "countercommunity" in a very interesting general discussion of anarchist political culture; see S. Gemie, "Counter-Community: an Aspect of Anarchist Political Culture", Journal of Contemporary History, 29 (1994), pp. 346-367.

48. I review the literature in Levy, "The Italian Socialist Party and the Second International". A very good organizational account is James Miller's, From Elite to Mass Politics: Italian Socialism in 
Just as Italian life was still largely defined within a local dimension, so too were socialist politics. ${ }^{49}$ A socialist presence was far more pervasive within the local government and rich political subcultures of the northern industrial suburbs, central Italy and Apulia. But the linkages between socialist politics and the world of work were mediated through labour institutions heavily influenced by the anarchists and syndicalists. Throughout the prewar period organized labour achieved at most a ten per cent union density. ${ }^{5 \circ}$ With the important exception of Federterra, unions were weak, and even Federterra was in fact representative of a regional power within the Po Valley's unionized agrarian workforce. FIOM only became important in the immediate prewar period. More important for the mass mobilization of workers were the widespread and deeply popular Chambers of Labour, which formed the backbone of the Italian tradition of the rolling general strike, not so much to be used for collective bargaining in economic disputes but rather to gather support when workers were shot in demonstrations or strikes. These sad events generated the emotional energy of the "second culture" because through these experiences anticlericalism, antimilitarism and a generic republicanism were kept alive. ${ }^{\text {II }}$ Thus, as we have seen, the massive protest wave of June 1914, the Red Week, was disseminated through them.

the Giolittian Era, I900-I9IS (Kent, 1990). A recent review of the history of the PSI during this era can be found in Z. Ciuffoletti, Storia del PSI. Le origini e l'età (Bari, 1992). However, the best study that combines an organizational account with an analysis of electoral, cultural and sociological factors is M. Ridolfi's Il PSI e la nascita del partito di massa I892-1922 (Bari, 1992). Other noteworthy studies of the culture of Italian socialism include: M. Degl'Innocenti, Geografia e istituzioni del socialismo italiano I892-19I4 (Naples, 1983) and S. Pivato, Movimento operaio e istruzione popolare nell'talia liberale. Discussione e ricerche (Milan, I986).

49. The importance of the regional dimension after unification for Italian culture and politics is discussed in C. Levy (ed.), Italian Regionalism: History, Identity, Politics (Oxford, I996).

50. John Davis's overview is excellent; see his "Socialism and the Working Class in Italy before I9I4", in D. Geary (ed.), Labour and Socialist Movements in Europe before I9I4 (Oxford, 1989), pp. I82-250.

51. For the pattern of general strikes, see Lotti, La settimana rossa and Murtaugh, Labor Protest. Although there is no recent single monograph devoted to the Italian Chamber of Labour, there is the older but still valuable discussion in Giovanni Procacci's La lotta di classe agli inizi del secolo $X X$ (Rome, 1970), pp. 53-65 and also Barbadoro, Il sindacato, pp. 631-784. In English there is one rather old but interesting Ph.D. dissertation available; see K.J. Kirkland, "The Italian Chambers of Labour, I890-19I4. The Formation of Working-Class Consciousness" (Ph.D., University of Michigan, 1976). However, there are many excellent local studies of the camere del lavoro. For examples of edited volumes and monographs see: Sereni, Camera del Lavoro; M. Bonaccini and R. Casero (eds), La Camera del Lavoro di Milano dalle origini al 1904 (Milan, 1975); A. Agosti and G.M. Bravo (eds.), Storia del movimento operaio, del socialismo e delle lotte sociali in Piemonte, vols I and 2 (Bari, I979); G. Perillo and C. Gibelli, Storia della Camera del Lavoro di Genova (Rome, 1980); various authors, Profondo Nord: la Camera del Lavoro di Brescia I892-I982 (Rome, I985); various authors, Il sindacato nel bolognese: le Camere del Lavoro a Bologna dal I893 al 1960 (Rome, 1988); N. Capitini Maccabruni, Liberali, socialisti e Camera del Lavoro a Firenze nell'età giolittiana (I900-I9I4) (Florence, I990); S. Alcara, La Camera del Lavoro della Spezia dal Igor al Igog (Rome, 1993). 
If these were the general "opportunity structures" through which syndicalism thrived, nevertheless it is still possible to be more specific about certain areas and moments which were more conducive to it, although perhaps it is difficult to propose "iron laws". Local studies, a particularly strong tradition in Italian historiography, allow us to paint a detailed picture.

Syndicalism gained support in artisanal and agrarian Italy, in a belt stretching from Rome to the Po Valley, and also in Apulia in the boot of Italy. Although syndicalism was important in the labour politics of Naples, like much of the local left it was sui generis. In Sicily there was a presence amongst the sulphur miners and in some of the larger towns and cities, but the Sicilian movement was rather removed from the centre of gravity of syndicalism during the Giolittian era. Syndicalism also had success in highly industrialized zones possessing specific characteristics. For example, Sestri Ponente, Terni and Piombino were areas where vast, modern chemical factories, iron and steel complexes and shipyards introduced a newer and less skilled working class into plants which lacked older socialist traditions of trade union organization. Syndicalism also gained support in industries where the right to strike was forbidden so that economic disputes escalated rapidly into confrontations with the state. Thus the La Spezia arsenal and the railways are good examples. $^{52}$

52. For Rome, see P. Salvatori and C. Novelli, Non per oro ma per libertà. Lotti sociali a Roma 1900-I926 (Rome, 1993). For Piombino and the island of Elba, see P. Bianconi, Il movimento operaio a Piombino (Florence, 1970); P. Favilli, Capitalismo e classe operaia a Piombino (I86I-I9I8) (Rome, 1974); U. Spadoni, Capitalismo industriale e movimento operaio a Livorno e all'Isola d'Elba (I880-1913) (Florence, 1979); U. Chiaramonte, Gli scioperi nella siderurgia a Piombino (Domodossola, 1983). For Livorno, see N. Badaloni and F. Pieroni Bortolotti, Movimento operaio e lotta politica a Livorno 1900-1926 (Rome, 1977), and T. Abse, Sovversivi e fascisti a Livorno: Lotta politica e sociale (I918-1922) (Milan, I99I). For Terni, see G. Canali, "Tradizione e cultura sovversiva in una città operaia: Terni”, in R. Corvi and G. Galli (eds), Storia delle regioni. L'Umbria (Turin, 1989), pp. 66I-703 and M. R. Porcaro, "Operaie ribelli e 'chiasse': le centurinarie", in ibid., pp. 707-733. For Genoa and its hinterland, see Perillo and Gibelli, Storia della Camera del Lavoro di Genova. For the province of Parma see fn. I8. For the ferrarese, see A. Roveri, Dal sindacalismo a fascismo. Capitalismo agraria e socialismo nel ferrarese (Florence, 1972). For Piacenza, see T. Sykes, "Il sindacalismo rivoluzionario nella Camera del Lavoro di Piacenza: un esperimento di 'azione diretta' (1906-1910)", Ricerche storiche, 7 (1978). For Massa-Carrara, see L. Gestri, Capitalismo e classe operaia in provincia di Massa-Carrara (Florence, 1976). For a recent study that examines the persistence of a syndicalist political culture in a "white" Catholic area of the north see, R. Bernardi, Sindacalismo rivoluzionario e movimento operaio a Brescia (Milan, 1994). For Naples see, M. Fatica, Origini del fascismo e del comunismo a Napoli (I9II-I9IS) (Florence, 197I); M. Marmo, Il proletariato industriale a Napoli in età liberale (I880-I9I4) (Naples, I978); G. Aragno, Socialismo e sindacalismo rivoluzionario a Napoli in età giolittiana (Rome, 1980); S. Fasulo, Storia vissuta del socialismo napoletana (I896-I95I) (Rome, I99I). For Sicily, see S. Fedele, "Il movimento sindacalista rivoluzionario in Sicilia negli anni I9II-I2", Ricerche storiche, 5 (1975). For the arsenal at La Spezia, see G. Bianco and C. Constantini, "'Il Libertario' dalla fondazione alla guerra mondiale", Movimento operaio e socialista, 8 (1960), pp. 62-90; A. Bianchi, Storia del movimento operaio di La Spezia e Lunigiana (Rome, 1975); Alcara, La Camera del Lavoro della Spezia. For the railway workers, see Bernardi, Il Sindacato Ferrovieri. 
We have had cause to mention the short-lived importance of syndicalism in much of the Po Valley. However, in Apulia the syndicalists became far more important due to the unusually concentrated populations of agricultural workers in the agro-towns, particularly intransigent absentee landlords and the frontier-zone mentality of an area of Italy recently cultivated for the world market in which the Church had few organizations and these, in any case, were mostly connected to the landlords. In many respects, in fact, Apulia approximated the conditions of Andulusia. ${ }^{53}$

But there was also the prewar syndicalism of Milan and Turin. Though never as consistent as Apulia, the upsurges of I9II-I9I3 were preceded by a decade of molecular activity on the part of syndicalist organizers and their sympathizers. Indeed, a form of proto-syndicalism operated through the POI in Milan in the I880s and I89os, while both cities saw notable syndicalist factions in their respective local PSI sections in 1904-1906. After the expulsion of the syndicalists from the PSI in 1908, they took part in libertarian influenced neighbourhood organizations in the newer working-class suburbs of both cities. Here these centri studi sociali accommodated selfeducated workers who discussed an eclectic mixture of anarchism, syndicalism and Marxism and formed grass-roots alliances so important for the waves of protest in I9I4 and 19I7-1920..$^{54}$

But what types of workers supported syndicalism in Milan or Turin? Once one gets down to micro-studies of industrial syndicalism, identifying a "natural constituency" seems a fruitless exercise. For instance, it has been argued that syndicalism was attractive to young unskilled factory workers in Milan, but equally that semiskilled workers employed in Milan's railway carriage and bicycle factories were overrepresented. Moreover, the syndicalists had a consistent following amongst the city's gas workers. ${ }^{55}$ On the other hand, my own work on Turin identifies a small group of skilled metalworkers as being the nucleus of both syndicalist

53. For Apulia, see E. Volpicella, "Per un'indagine sul sindacalismo rivoluzionario in Puglia: I. appunti sulle condizioni dei contadini di captianata agli inizi del'9oo", Annali della facoltà di scienze politiche, Università di Perugia (Perugia, 1973-1976); F. Snowden, Violence and Great Estates in the South of Italy: Apulia 1900-1922 (Cambridge, 1986); Allegato, Sindacalismo rivoluzionario e comunismo in Puglia; A. Pepe, "Il sindacalismo pugliese nel primo Novecento", in L. Massella and B. Salvemini (eds), Storia d'Italia. Le regioni dall'Unità a oggi: La Puglia (Turin, I989), pp. 779810.

54. For Milan, see M. Antonioli, "Il movimento anarchico milanese agali inizi del secolo", in various authors, Anna Kuliscioff e l'età del riformismo (Rome, 1978), pp. 275-290; A. Riosa (ed.), Il socialismo riformista a Milano agli inizi del secolo (Milan, 1981). For Turin, see Levy, Gramsci and the Anarchists, pp. 39-43, 46-52.

55. Pepe, La lotta di classe, and Antonioli, "Sindacalismo rivoluzionario italiano", p. I57. For the gas workers, see G. Paletta and C. Perego, "Organizzazione operaia e innovazioni technologiche. La Lega Gasisti di Milano 1900-1915”, Annali della Fondazione Giangiacomo Feltrinelli, I2 (1982), pp. 49-86; R. Coriasso, Giacche Blu (Milan, 199I). 
and anarchist labour organizations after 1910. ${ }^{56}$ It has also been argued that certain factories developed micro-syndicalist political cultures which then become embedded over a decade or more in the labour politics of a particular establishment. Thus, for example, it is quite easy to trace continuities between 1910 and 1920 in such Milanese industrial landmarks as Alfa-Romeo, Pirelli and Franco Tosi. ${ }^{57}$ Fear of the meddlesome state may also explain why syndicalists could broaden their appeal and win arguments if not converts in industrial settings such as Milan and Turin. In I9I2 and I9I3 there was rather consistent opposition to Giolitti's state insurance reforms using arguments against the "servile state", as advanced by the contemporaneous and odd coalition of the British "rebel" left and Hillaire Belloc. These themes were once again advanced with considerable success in $1919-1920 . .^{8}$

Finally, some students of syndicalism have taken the biographical approach. Certain tough but pragmatic labour organizers were the key to success of local syndicalist unions or Chambers of Labour, it is argued. Thus Alberto Meschi successfully organized the marble quarry miners of Massa-Carrara, ${ }^{59}$ Riccardo Sacconi was notably important for syndicalism in the area between Pisa and Florence, ${ }^{60}$ Giuseppe Di Vittorio mobilized the landless labourers of Apulia, ${ }^{61}$ and Antonio Negro played a signal role in creating a syndicalist stronghold in the Genoese industrial hinterland around Sestri Ponente. ${ }^{62}$ Opinion about Armando Borghi is divided. $\mathrm{He}$ was never an industrial worker, always a professional journalist or organizer, and in his youth and later, during his long exile in the USA, a confirmed individualist anarchist. ${ }^{63} \mathrm{Up}$ to $19 \mathrm{I} 8$ and during the biennio rosso, syndicalist

56. Levy, Gramsci and the Anarchists, pp. 39-43, II9-166.

57. Duccio Bigazzi's magisterial history of a factory provides evidence: see D. Bigazzi, Il Portello. Operai, tecnici e imprenditori all'Alfa-Romeo 1906-1926 (Milan, 1988).

58. G. Candeloro, Storia d'Italia, vol. 8 (Milan, 1977), pp. 342-346; Levy, "Malatesta in Exile", pp. 285-290; Levy, Gramsci and the Anarchists, p. I29.

59. H. Rolland, Il sindacalismo anarchico di Alberto Meschi (Florence, 1972); Gestri, Capitalismo e classe operaia; various authors, Convegno di studi sul sindacalismo libertario di Alberto Meschi (Carrara, 1994).

6o. L. Gestri, "Sacconi, Riccardo", in Andreucci and Detti (eds), Il movimento operaio, vol. 4, pp. $444-448$.

6. Pistillo, Giuseppe Di Vittorio.

62. L. Cagna, "Antonio Negro: Dalla reazione del 1898 al fascismo", Movimento operaio e socialista, I9 (1973), pp. I25-I45.

63. Armando Borghi's entertaining if misleading memoirs are worth consulting, see A. Borghi, Mezzo secolo di anarchia (Naples, 1954). For recent biographies and information on his life, see: F. Tarozzi, "Armando Borghi organizzatore politico-sindacale a Bologna (I907-I9II)", Bollettino del Museo del Risorgimento di Bologna (Bologna, 1983); various authors, Armando Borghi: un pensatore e un agitatore anarchico (Pistoia, I988); various authors, "Armando Borghi nella storia del movimento operaio italiano ed internazionale", Bollettino del Museo del Risorgimento (Bologna, 1990); Antonioli, Armando Borghi e l'Unione Sindacale Italiano; E. Falco, Armando Borghi e gli anarchici italiani I900-1922 (Urbino, 1992). 


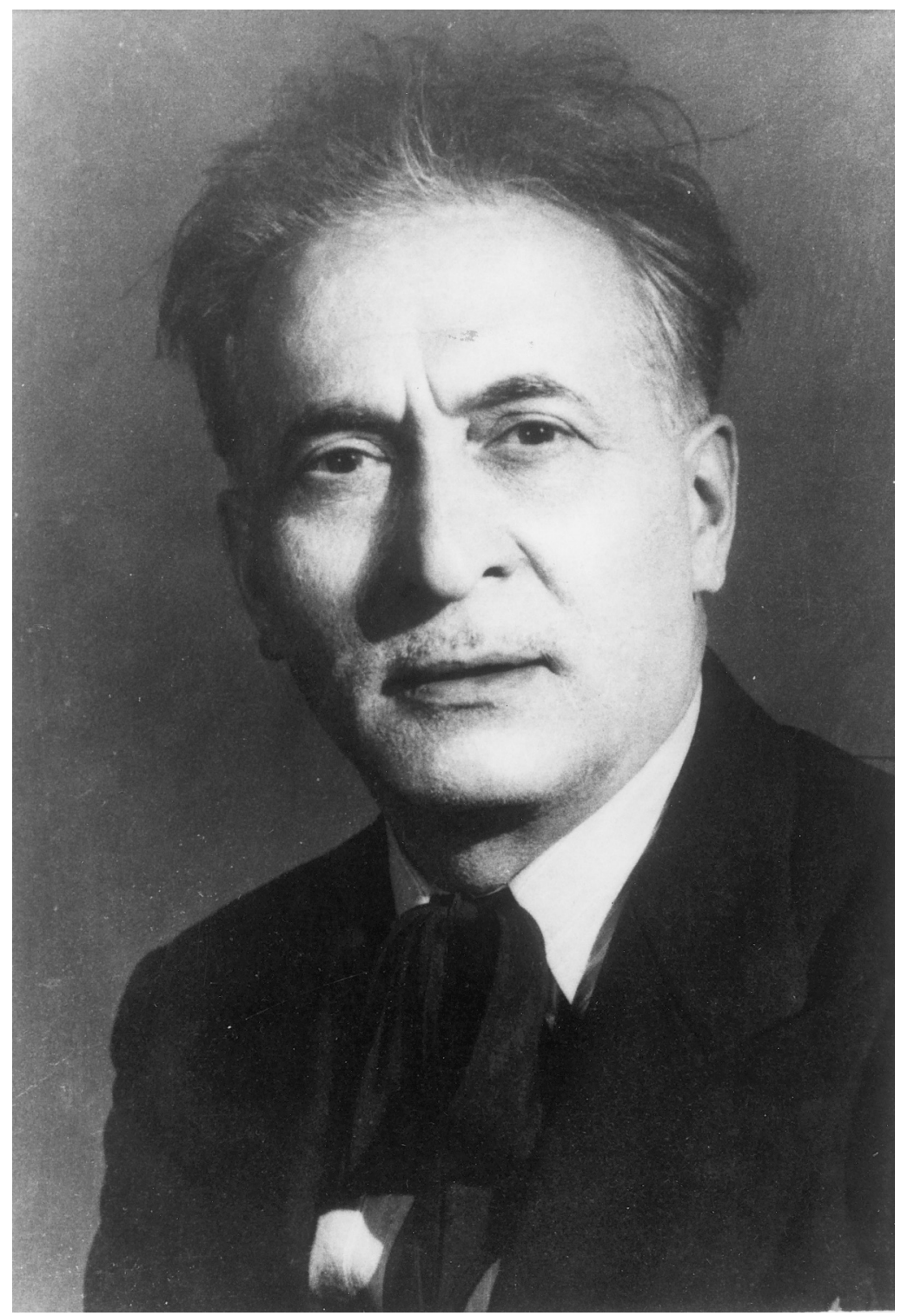

Figure 4. Armando Borghi (1882-1968), a militant anarchist involved in the Italian syndicalist movement, who was arrested and imprisoned several times for anarchist activities and organizing strikes from 1903. He was a representative of the Unione Sindacale Italiana at the congress of the Communist International in 1920. He condemned communist authoritarianism and adhered with the USI to the syndicalist International Working Men's Association. After living in exile in several European countries he left for the USA in 1926.

International Institute of Social History, Amsterdam 
newspapers bound the USI together. Even if Armando Borghi was a fervent anti-interventionist, still it is not difficult to picture him as an anarchist version of the prewar syndicalist journalists who left the USI to support the UIL. In any case, the bread-and-butter results which syndicalist organizers gained for workers rather than their ideological message won a loyal local following.

If there are no "iron laws" underpinning the sociology of Italian syndicalism, a series of plausible parameters have been advanced which await historians to test their consistency. In areas where class tensions remained unresolved, especially in company or "state" towns and in the agro-towns of Apulia, in areas where the middle classes were exiguous and usually viewed as profiteers of a newly created, highly concentrated and geographically separate working class, syndicalism and the older libertarian "second culture" became firmly implanted. In contrast, areas where the labour movement was capable of developing a rich tissue of trade unions and cooperatives (although syndicalists were not alien to the cooperative movement in their stronghold in Parma), and concurrently were able to gain the sympathy of the middle classes, were zones where syndicalism never really achieved much support. Thus, perhaps, the province of Reggio Emilia could serve as prime evidence for such an approach. ${ }^{64}$

This overview of the sociology of Italian syndicalism echoes the most recent summary of global trends. Disproportionate numbers of agricultural workers fits van der Linden and Thorpe's definition of "project workers", and their emphasis on workers of the "second industrial revolution", especially factory workers in modern establishments, is confirmed in the Italian case in the upsurge of syndicalism and syndicalist sentiment amongst the metalworkers of the north. Moreover, van der Linden's recent amendments to the earlier overview are a useful addition, especially both his new emphasis on the autonomous effects of political culture and the negative and positive effects of state intervention in industrial relations. These seem particularly appropriate for the Italian case. ${ }^{65}$ I will discuss the relationship of the state and syndicalism, while the positive correlation between the libertarian political culture and Italian syndicalism has already been emphasized, though this study of political culture can be profitably extended to histories of specific factories. Finally, it is also best not to underestimate the autonomous influence of charismatic organizers. In Britain Tom Mann influenced a rank-and-file far outside the much smaller syndicalist political

64. For the relationship between the cooperative movement and syndicalism, see U. Sereni, Il movimento cooperativo a Parma tra riformismo e sindacalismo (Bari, 1977). This hypothesis was advanced at the Piombino conference by Procacci but it still has not been systematically tested by historians, see G. Procacci, "Intervento", Ricerche Storiche, 5 (I975), pp. I09-II4.

65. van der Linden and Thorpe, "The Rise and Fall of Revolutionary Syndicalism"; M. van der Linden, "Second Thoughts on Revolutionary Syndicalism”, Labour History Review, 63, (I998), pp. $87-90$. 
culture. ${ }^{66}$ However, even in the more robust Italian case, Meschi, Di Vittorio or Corridoni personified syndicalism for workers who were hard put to follow the intellectual acrobatics of Arturo Labriola or Enrico Leone.

\section{IDEOLOGIES OF SYNDICALISM}

The syndicalist intelligentsia and syndicalist ideology have been overresearched, or at least new research questions which might synthesize results in new directions have been strangely lacking. This is perhaps due to the prominence the intellectuals gained through written texts. The syndicalist intelligentsia were heavily represented within the journals and literature of the Italian left of the early twentieth century. Many of the early theorists of syndicalism were university professors and/or journalists and their initial prominence within the PSI was due to a lack of coherent national leadership within the party or an identifiable corpus of ideological doctrine. Syndicalist intellectuals gained power through astute management of party journals. With the expulsion of the syndicalist current within the PSI, the new lower middle-class stratum of labour organizers provided a closer link with working people. We lack a social history of this group, but such an undertaking would reveal much about syndicalism after I9IO and uncover important aspects of the radical populist middle-class culture of the I9Ios.

At their best these mobile professional organizers drew on a wealth of different national and local movements, since many had been active elsewhere in Europe and the Americas. But mobility could also indicate an underlying fickleness, a lack of clear principles. Professional itinerant organizers in the Po Valley might spend one year in an agricultural Chamber of Labour, another in industrial Terni and a third in Elba or Savona. They gained experience at organizing strikes, but lacked a deep-rooted connection with any labour movement in particular. A group biography of the chief labour organizers (Corridoni, the Pasella brothers, the De Ambris brothers, the Bitellis, Bianchi etc.) reveals a distinctive pattern. ${ }^{67}$ Most were either journalists or lawyers by profession (perhaps Corridoni is an exception to the rule) who served apprenticeships as provincial secretaries in Chambers of Labour. But at the end of many years of labour organizing, these proponents of the class struggle abandoned syndicalism for republicanism, and in many important cases after the war, fascism. No-one has yet advanced a completely satisfactory explanation as to why these syndicalist labour organizers, who excelled at heightening tensions between sharecroppers and landless labourers before the war, could be by the early twenties under the

66. J. White, "Syndicalism in a Mature Industrial Setting: The Case of Britain", in van der Linden and Thorpe, Revolutionary Syndicalism, pp. IOI-II8; idem, Tom Mann (Manchester, 199I); C. Tsuzuki, Tom Mann I858-1941:The Challenges of Labour (Oxford, 199I).

67. Procacci, "Intervento". 
banner of fascism leading all other agricultural strata in a counterattack against the landless labourers. Perhaps an initial republicanism, particularly strong amongst syndicalist labour organizers, would eventually pit them against the internationalist and pacifist socialists when war came. And then again, perhaps their very mobility, their experience of living insecure lives as marginal provincial intellectuals, made them susceptible to view their rank-and-file as passive cannon fodder. Sorelian concepts permeated their journals and the "later Sorel", the Sorel of the myth of violence, was more readily accepted by them than the first wave of syndicalist professors. Their "Sorel" was digested second- and third-hand, using the popular if misleading interpretations of Angelo Olivero Olivetti and Sergio Panunzio. ${ }^{68}$ While these intellectuals had little if any direct influence or contact with labour organizations, indeed they were always closer to nationalist circles, their particularly elitist variety of Sorelianism shaped many of the labour organizers' world views.

The two most important intellectuals in Italian syndicalism were undoubtedly Arturo Labriola and Enrico Leone. ${ }^{69}$ Both claimed to be the most faithful Marxists in Italy and denounced anarchism and the "anarchic" behaviour of Italian social protest in no uncertain terms. They, however, were intransigent supporters of the class war by a modern industrial working class. They disagreed with the central tenet of Marxian theory - Marx's labour theory of value - and preferred to employ neoclassical marginalism. Marxian economics were considered unscientific, but these theoreticians still felt that Marx's identification of class struggle as the motor of historical change was valid. Socialism was the product of a proletarian elite, they argued. $^{70}$ A "healthy" working class required an avoidance of state intervention. They opposed Giolittian protectionism of heavy industry which they termed industrial feudalism. A successful proletariat could not rely upon the favours of Giolitti or the capitalist state. In their free trade ideology they shared much with liberal economists such as Einaudi, Giretti and Cabiati, and in addition, their celebration of heroic young elites, attracted the supportive attentions of Vilfredo Pareto. ${ }^{7 \mathrm{~T}}$

Arturo Labriola's ingrained republicanism and his involvement in Neapolitan politics led him to an endorsement of the Libyan War, moderate sui generis socialism in Naples, collaboration with Giolitti and finally opposition to Mussolini from exile in Paris. Even here he was not consistent, since he endorsed Mussolini's invasion of Abyssinia in 1935 but, after the Second World War and at the end of his life, he was endorsed by the communists

68. J.J. Roth, The Cult of Violence: Sorel and the Sorelians (Berkeley, CA, 1980), p. 79.

69. See footnotes I4 and I5.

70. Riosa, Il sindacalismo rivoluzionario, p. I5I.

7I. P. Favilli, "Economia e politica del sindacalismo rivoluzionario. Due riviste di teoria e socialismo scientifico: Pagine Libere e Divenire Sociale”, Studi storici, I6, (I974), pp. 213, 216, 224-225; idem, Storia del marxismo italiano, p. 472. 
for office in Naples! Leone remained more consistent. He was a Sorelian, but an "early Sorelian". His favourite text was Sorel's L'avenir socialiste des syndicats, in which he drew support for the endorsement of the syndicalist union as a prefiguration of a postcapitalist society. However, Leone was dead set against the "later Sorel". Violence was never accepted by Leone, and he also opposed Bergsonian idealism (as did Labriola): both men were firm positivists. ${ }^{72}$

Leone returned to the PSI during the war and wrote extensively in the socialist press during the biennio rosso, arguing that Russian Sovietism was merely a variety of syndicalism. At the same time he also wrote widely for the USI. In many respects his position was rather similar to American Daniel De Leon's. Both argued that the working class, through elections and industrial organization, would eventually carry out a peaceful revolution in the wake of the climactic general strike against the capitalist state. ${ }^{73}$

This conveniently leads us on to the relationship between anarchists and syndicalists. Polemical exchanges were always present before 19I4, even if the anarchists were one source for the syndicalist movement. As previously mentioned, syndicalist intellectuals and many syndicalist labour organizers saw anarchism as an epiphenomenon of the premodern structures of Italian society. In their minds these concerns were reconfirmed by the events of the Red Week in 19I4. There was also the rather unfortunate fact that in I909 Sorel evinced no sympathy after the execution of the Catalan libertarian educationalist Francisco Ferrer $^{74}$

But the most important examples of tensions between anarchists and syndicalists occurred when the anarchist Armando Borghi led the USI during the biennio rosso. ${ }^{75}$ Although there has been some interesting work for this period, there is still plenty of scope for further investigation here.

Debates amongst anarchists about their position within the USI erupted in $1919-1920 .{ }^{76}$ First there were anarchists who considered themselves nonsectarian minorities within the CGL itself. Thus the anarchists in a leadership position in the local branch of FIOM endorsed Gramsci's interpretation of the factory council movement in Turin and steered clear of the USI. Quite naturally Borghi and other anarchist cadres within the USI wanted all anarchists to give them their undivided support. However,

72. Riosa, Il sindacalismo rivoluzionario, p. 213; Furiozzi, Il sindacalismo rivoluzionario, p. I8.

73. For De Leon's influence in Europe, see J.A. Stevens, "Daniel De Leon and European Socialism, I880-1914", Science and Society, 44 (1980), pp. II9-I43.

74. G.B. Furiozzi, "Sorel e gli anarchici italiani", Ricerche storiche, 5 (I975), pp. I79-I88; idem,

"Polemiche tra sindacalisti rivoluzionari e anarchici italiani nell'età giolittiana", Ricerche storiche, II (I98I), pp. 495-5I2.

75. In general, see Falco, Armando Borghi e gli anarchici italiani.

76. I discuss this in Levy, "Italian Anarchism", p. 67. See also the comments by Antonioli in his Armando Borghi, pp. 46-83. There is an interesting correspondence between Luigi Fabbri, a close associate of Malatesta's, and Borghi (especially letters dated I2 and I7 June I920). These are found in the Luigi Fabbri papers in the International Institute of Social History, Amsterdam. 


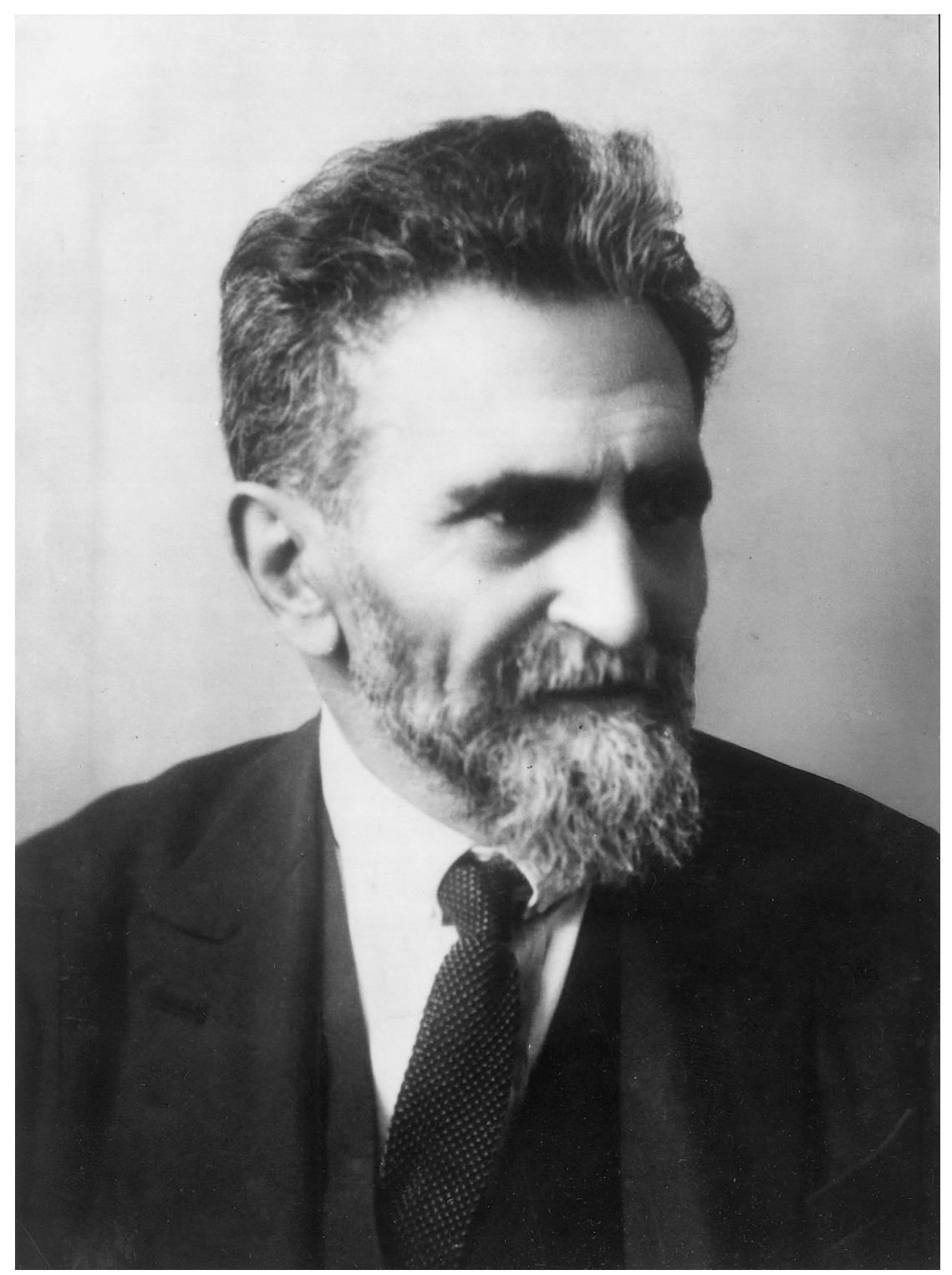

Figure 5. Errico Malatesta (1853-1932), anarchist militant and thinker. He was a member of the Naples section of the First International. From 1872 he was a member of the Fraternité intime, derived from Bakunin's earlier inner group of I864. Imprisoned many times for his revolutionary activities from 1873 onwards, and repeatedly forced into exile to evade imprisonment, he prepared the unsuccessful revolt before and during the Red Week in June I9I4 of the Romagna. He lived virtually under house arrest during the last years of his life.

International Institute of Social History, Amsterdam 
the closest followers of Malatesta opted for a neutral position. Earlier, at the 1907 Amsterdam International Anarchist conference, Malatesta argued against Pierre Monatte's open endorsement of syndicalism by anarchists. ${ }^{77}$ The logic of trade unionism, Malatesta had reasoned, was a form of economism. Anarchists should adopt a libertarian position in whatever trade union they found themselves. Furthermore, general strikes on their own would never usher in a social revolution.

In any case, after I9I8 relations in the USI between pure syndicalists and openly declared anarchists were rarely untroubled by disputes over doctrine and tactics. Alibrando Giovannetti, secretary of the USI's metalworkers' union, and a believer in nonviolence, saw peaceful occupations of factories as a substitute for insurrection. ${ }^{78}$ Angelo Faggi (recently deported from the USA due to his activities in the IWW), chief agricultural organizer in the piacentino, and Giuseppe Di Vittorio of the Apulian peasant leagues, argued for the contestation of local and parliamentary elections. In I9I9, at the first congress of the USI after the war, Borghi had to contend with a strong minority faction of electoralists and another which wanted to dissolve the USI and enter the CGL. ${ }^{79}$

It should also be added that the expansion of the USI in 1919-1920 was largely based upon the anarchist strongholds in the Chambers of Labour. Due to the fact that most grass-roots syndicalist organizers had become interventionists, anarchist militants took a major role in reviving the USI at the base. The attempt to create industrial unions in the metalworking, mining or other industries were largely paper exercises. The real base of the metalworkers' union, for example, was in fact the Chamber of Labour of Sestri Ponente, the miners were centred in the Chambers of Labour of Arezzo and Massa-Carrara; while the agricultural industrial union was based in the Chamber of Labour of Piacenza and the peasant leagues of Apulia. ${ }^{80}$

A summary of historical work on the dimensions of the Italian syndicalist ideology would be incomplete without returning to that oldest chestnut of them all: the relationship between Italian syndicalism and the rise of fascism. I have already noted the role of certain intellectuals in creating the social

\footnotetext{
77. For Malatesta's position on syndicalism, see M. Antonioli, "Errico Malatesta, l'organizzazione operaia e il sindacalismo (I889-I9I4)", in idem, Azione diretta e organizzazione operaia. Sindacalismo rivoluzionario e anarchismo tra la fine dell'Ottocento e il fascismo (Manduria, 1990), pp. 203-283. 78. Giovannetti has been sadly overlooked by historians. He was representative of the middlerange syndicalist organizer; see C. Levy, "SAC och den internationella solidariteten - hur svenska syndikalisten hjälpte offren för den italienska fascismen”, Meddelanda frän Arbetarrörelsens Arkiv och Bibliotek, I4-I5 (1980), pp. 38-39.

79. Faggi has also been overlooked, but see F. Taddei, "Faggi, Angelo", in Andreucci and Detti, Il movimento operaio, vol. 2, pp. 279-282. For Di Vittorio, see Pistillo, Giuseppe Di Vittorio. The best review of the USI's Parma congress is still found in Bertrand's unpublished Ph.D. dissertation: see "Revolutionary Syndicalism in Italy", chs 5 and 6.

80. A breakdown of the USI's organizations is found in Bertrand, "Revolutionary syndicalism", p. 29I; Guerra di Classe, 26 January I9I9, p. I; 29 May I920, p. 3.
} 
imperialism of the Nationalist Association and I have pointed to the republican and democratic impulses behind the war interventionism of USI militants in 1915. Further, I have hinted at the attractions of Sorelian irrationalism for quite a few prewar labour organizers. What I hope these hedged comments make clear is that a direct line of descent from syndicalism to fascism is hard to draw. Sternhell and associates have recently argued that in France and Italy syndicalism provided one of the components for the national socialism that created the fascist synthesis. I have always found this approach very unsatisfactory. ${ }^{81}$ It is certainly true that Mussolini surrounded himself with syndicalists after 1915, but that did mean that interventionists or fascists of the "first hour" remained with their Duce very long. However, on the other hand, I do not think that Mussolini was merely an opportunist who, when his luck turned in late 1920, used what and who he could to seize power. If that was the case then fascism was never more then a Mussolinian charade. I think it should be treated more carefully and seriously than that. Mussolini used syndicalists and their union-organizing skills to create a state within a state in the Po Valley. ${ }^{82}$ He later played the union card between 1922 and 1926 either to cajole the rump of the CGL into his first governments before his turn to complete dictatorship, or to cow capitalists who, by 1924-1925, were distinctly nervous of Mussolini's behaviour. $^{83}$

Furthermore, there is the question of Mussolini's ur-competitors: D'Annunzio and his Fiumian Legionnaires. Alceste De Ambris, leading militant in the USI and later in the UIL, wrote D'Annunzio's Charter of Carnaro, which, in its garbled mysticism and demagogic promises, was an anticipation of Mussolini's corporative state. ${ }^{84}$ However, Mussolini kept his distance from Fiume and particularly the poet's negotiations in January 1920 for a "March on Rome" with components of the anti-interventionist Italian left. When Giolitti crushed the occupation of Fiume in December 1920, the legionnaires went in two directions. Some used their "military talents" to intimidate the socialists and the left in the Po Valley by enlisting in the fascist squads, while others joined a populist antifascist grouping called the Arditi del Popolo. ${ }^{85}$ This organization fell apart after being disowned by the

8I. C. Levy, "Fascism, National Socialism and Conservatives in Europe, 1914-1945: Issues for Comparativists", Contemporary European History, 8 (1999), pp. 99-100.

82. E. Gentile, Storia del Partito Fascista I9I9-1922. Movimento e milizia (Bari, I989).

83. See the most recent in-depth analysis of the Torinese case by Franklin Adler, Italian Industrialists from Liberalism to Fascism, I906-1934 (Cambridge, I995).

84. R. De Felice (ed.), Sindacalismo rivoluzionario e fiumaneismo nel carteggio De AmbrisD’Annunzio (I9I9-I922) (Brescia, I966).

85. There has been immense amount of work done on D'Annunzio at Fiume. I summarize the literature about the aborted "March on Rome" in C. Levy, "Charisma and Social Movements: Errico Malatesta and Italian Anarchism”, Modern Italy, 3 (1998). For a representative sample of accounts, see M. Ledeen, D'Annunzio a Fiume (Bari, I975); F. Perfetti, Fiumanesimo, sindacalismo e fascismo (Rome, 1988); Berghaus, Futurism and Politics, pp. I39-I44. Generally speaking, these 
communists and the socialists, while simultaneously being suppressed by the government. Other fascist syndicalist dissidents mounted a rearguard action against Mussolinian dictatorship in 1924-1925.

The relationship between populist syndicalism and fascism was uncertain and tense. Indeed, the fascist syndicates after 1926 should not be automatically equated with syndicalism before 1926. Although the corporative state underpinned the dissolution of parliamentary democracy and free trade unions after 1926 and some of its ideological influences are found within the writings of syndicalists, it can also be demonstrated that much of its doctrine can be traced either to Catholic social thought or to the conservative juridical writings of nationalist Alfredo Rocco. ${ }^{86}$ The biographical approach employed by certain students of syndicalism has given us a rather misleading or simplistic picture. Indeed the contrasting biographies of the syndicalists Edmundo Rossoni and Cesare Rossi demonstrate the complexity of this history. In short, a close analysis of the relationship between the evolution of Fascism and syndicalism between I92I and 1926 still awaits an historian who can assess a variety of inputs and not merely the distinctive roles of certain syndicalist intellectuals or populist organizations in the creation of the totalitarian dictatorship. ${ }^{87}$

It is now time to take stock of the arguments presented in this section of the article. In the first place Italian syndicalist ideology originated in debates within the Marxist currents of the PSI. Secondly, syndicalist ideology was also closely associated with an older populist republicanism that, at least until 1914, set it apart from its French counterpart. For many Italian syndicalists the French Revolution and the French republic were still potent threats to the Italian status quo, while at least rhetorically, the republic was French syndicalism's enemy. This populist republicanism also meant that electoralism constantly resurfaced in the movement, although communal and local elections were more easily assimilated to syndicalism's federalist

works take D’Annunzio's actions very seriously (although Berghaus has some amusing episodes), whereas a recent biography highlights the element of bluff to it all; see J.R. Woodhouse, Gabriele D'Annunzio: Defiant Archangel (Oxford, 1998). Although the Arditi del Popolo have been examined by many historians, until recently we have lacked a monograph devoted to this interesting phenomenon, but see now M. Rossi, Arditi, non gendarmi! Dall'arditismo di guerra agli Arditi del Popolo 1917-1922 (Pisa, 1997).

86. For fascist dissidents see P. Lombardi, Per la libertà: la dissidenza fascista tra "mussolinianismo" e Aventino (1923-25) (Milan, 1990). For Rocco, see De Grand, The Italian Nationalist Association. 87. For examples of the biographical approach, see Roberts, The Syndicalist Tradition; F. Perfetti, Il sindacalismo fascista (Rome, 1988); Sternhell et al., The Birth of Fascist Ideology. For Rossoni, see J.J. Tinghiano, Edmondo Rossoni from Revolutionary Syndicalism to Fascism (New York, 199I). For Rossi, see M. Canali, Cesare Rossi (Bologna, 199I). For attempts to trace the origins of corporatism in the industrial relations of prefascist Italy, see A. De Bernardi, "Operai, sindacati e regime negli anni venti. Il caso di Milano", Società e storia, 40 (1988), pp. 335-378; idem, "Nazionalizzazione delle masse e mobilitazione del proletariato di fabbrica. Alle origini del fascismo", in M. Antonioli, M. Bergamaschi and L. Ganapini (eds), Milano operaia dall'8oo a oggi, vol. I (Milan, 1993), pp. $263-283$. 
doctrine and to the practices of Italian syndicalism's institutional stronghold, the Chamber of Labour. However, there was never an anarchosyndicalist current in the Italian movement. Italian syndicalists called themselves sindacalisti rivoluzionari, while anarchists, as we have seen, were either agnostic or faithful supporters of syndicalism as a tactic, but never advanced it as an end in itself. Even when the USI was dominated by anarchists after 1916, it never became an anarcho-syndicalist organization, and during the biennio rosso the anarchists' own national organization, the UAI (Unione Anarchica Italiana, Italian Anarchist Union), never recognized the USI as the sole organization for workers who were anarchists. Indeed for some anarchists, the factory council became the most suitable nonsectarian arena of operations. ${ }^{88}$

Nor did industrial unionism have a clear field in Italy. Before 19I4, Corridoni and other syndicalists active in the north may have used arresting arguments rather similar to those advanced by industrial unionists in Britain and the USA. However, although they advanced innovative arguments about organizing at the factory level, they never endorsed fully-fledged industrial syndicalism on the model of German Arbeiter-Unionen or the Canadian One Big Union. The federation of camere del lavoro, rather than the industrial commonwealth, was closer to their vision of a future noncapitalist society. ${ }^{89}$

Perhaps the greatest difference between Italian syndicalism and other national cases is its much greater, pervasive generic influence on Italian cultural and intellectual life before I9I5. Syndicalist modes of thought and argument attracted free trade liberals, "proto"-fascists, futurists, and gadfly modernists intellectuals associated with the Florentine journal, La Voce. Syndicalism in this form was another version of the pedagogic, modernizing and nation-building ideology that attracted so much of the disenchanted Italian intelligentsia of the liberal era..$^{\circ}$ In this respect, the universal "means

88. For the lack of usage of the term anarcho-syndicalist in Italy, see M. Antonioli, "Sindacalismo rivoluzionario e anarcosindacalismo", in idem, Il sindacalismo italiano dalle origini al fascismo (Pisa, 1997), pp. 157-167. For the French syndicalists and the French republican state, see Marco Gervasoni's pioneering articles, "Il linguaggio politico del sindacalismo d'azione diretta in Francia: la rappresentazione del sociale e la concezione dell'autonomia della C.G.T. di fronte alla stato repubblicano (I895-I9I4)", Società e storia, 47 (I996), pp. 77I-820; idem, "Libertà e 'autonomia' nell'immaginario delle Borse del Lavoro francesi tra anarchismo e socialismo”, Rivista storica dell'anarchismo, 3 (1996), pp. 5-29. For the factory councils, anarchists and syndicalism, see Levy, Gramsci and the Anarchists, chs 4 and 5 .

89. For an interesting discussion of the international context, see L. Petersen, "The One Big Union in International Perspective: Revolutionary Industrial Unionism, 1900-1915”, in J. Cronin and C. Sirianni (eds), Work, Community and Power (Philadelphia, PA, I983), pp. 49-87.

90. There has been much interesting work done on this theme: see R. Bellamy, Modern Italian Social Theory from Pareto to the Present (Cambridge, 1987); idem, Liberalismo and Modern Society (Cambridge, I992), pp. I05-156; R. Bellamy and D. Schecter, Gramsci and the Italian State (Manchester, I993); C. Duggan, "Francesco Crispi, 'political education' and the problem of Italian national consciousness, I860-I896”, Journal of Modern Italian Studies, 2 (I997), pp. I4I-I66. 
of exchange" were Sorel's texts and his own interventions in Italian newspapers and literary journals. Before 1920, Sorel had a greater impact on intellectual life in Italy then perhaps anywhere else; certainly more than in his native France. ${ }^{91}$ Sorelian key words and concepts permeated intellectual discourse, but Sorel's direct impact on syndicalism as a labour movement is very complex and often misleadingly portrayed. As we have seen, the chief pioneer syndicalist ideologists were attracted to the pre-Reflections on Violence "Sorel", while the more "violent" and "mythical" Sorel had a significant, but still relatively uncharted, importance for the intellectual life of the "second generation" labour organizers. However, at the grass roots, Sorel was ignored or considered too "difficult" or received suspiciously for his condemnation of free-thought "masonic" libertarian culture. In this respect, he was appreciated and employed by Italian neo-idealists from Croce to Gramsci in their battle against high and middle-brow positivist Italian culture and all its works. ${ }^{92}$

\section{ORGANIZATION AND PERFORMANCE}

One of the most interesting questions concerning the study of syndicalism in any national context is in what ways it had a unique impact upon the conditions and realities of the broader labour movement and upon workingclass life in general. This raises more general and interesting theoretical issues about the reception of ideology within social movements and the effects of the linguistic turn in social history for understanding the material effects of ideological and rhetorical discourse. This approach has been recently employed in an original, if flawed, account of the triumph of reformism within the French CGT, ${ }^{93}$ and a suggestive attempt to understand the culture of British syndicalism. ${ }^{94}$

Although the method has still not been employed in the Italian case and could produce interesting work, I instead shall use the methodologies of earlier work on French syndicalism as benchmarks to measure the unique effects of Italian syndicalism upon Italian industrial relations and workingclass subcultures. I have adopted opposing methods advanced by Peter Ste-

91. See Roth, Sorel and the Sorelians for a global overview. Jeremy Jennings's analysis of the impact of Sorel on French syndicalism is very good; see J. Jennings, Syndicalism in France (Basingstoke, 1990). But see also the impressive recent study of Sorel by Marco Gervasoni, Georges Sorel. Una biografia intellettuale. Socialismo e liberalismo nella Francia della belle époque (Milan, 1997). Other studies of Sorel in Italy include: V. Comparato (ed.), G. Sorel. Studi e ricerche (Florence, 1974); G.B. Furiozzi, Sorel e l'Italia (Messina-Florence, I975); S. Onufrio, Sorel e il marxismo (Urbino, 1979); G. Cavallari, Georges Sorel: archeologia di un rivoluzionario (Naples, 1994).

92. For the uses by Gramsci of Sorel, see Levy, Gramsci and the Anarchists, pp. 99-102, 197-199. 93. K.H. Tucker, Revolutionary Syndicalism and the Public Sphere (Cambridge, 1996).

94. R. Price, "Contextualizing British Syndicalism c.1907-c.1920", Labour History Review, 63 (I998), pp. 26I-276. 
arns ${ }^{95}$ and Roger Magraw. ${ }^{96}$ Stearns argued that French syndicalism was a cause without rebels. In other words, the impact of French syndicalism upon the outcomes of industrial disputes in France was minimal: syndicalism was a rhetorical smokescreen for reformist practices. More recently Magraw argued that French syndicalism was an integral part of working-class culture and, even if the economistic results were not that different from the efforts of reformists, it was the cultural and political context at the local level that mattered. In other words, cliometric methodology tells us little about how social actors perceived reality.

I have argued that Italian syndicalism was a subspecies of a broader libertarian "second culture". To this extent I endorse Magraw. However, if we measure the results and methods used by Italian syndicalists in industrial disputes, Stearns should not be discounted.

Agricultural disputes were essential to the history of the prefascist Italian labour movement, but here the practices of reformist socialist trade unionists were not that different from the syndicalist competition. The cumulative results of local studies of the Po Valley demonstrate that reformists were not opposed to using direct action to pressurize the Italian parliament into turning over funds to worker cooperatives and public works for unemployed landless labourers during the dead season. Reformists were equally capable of instituting boycotts, cutting vines and letting crops rot in fields to secure victory during strikes. Furthermore, neither did long-term strategic goals greatly vary. In the bolognese and ferrarese prewar reformists and syndicalists, and postwar maximalist socialists, all demanded the socialization of the land and the proletarianization of the sharecropper. All three aimed to control the hiring hall and did not hesitate to use violence and intimidation to achieve their goals. Ironically, the so-called antistatist syndicalists in their agrarian guise depended on Giolitti's system of favours to attract a following. Success or failure to attract monies from Rome swung peasant leagues behind or against syndicalism. ${ }^{97}$

If we turn to industrial syndicalism, a similar paradox is apparent in the epic strikes of metalworkers in Milan, led by the USI in 1913, and a nearly contemporaneous strike led by FIOM in Turin. ${ }^{98}$ As I have recently shown, this second strike had followed an initial strike in Turin organized by local anarchists and assisted by organizers from the USI. ${ }^{99}$ In the first anarchistorganized strike matters of principle were emphasized - the retention of

95. P. Stearns, Revolutionary Syndicalism in France: A Cause Without Rebels? (New Brunswick, NJ, I97I).

96. R. Magraw, Workers and the Bourgeois Republic (Oxford, I992), pp. 98-II5.

97. See the interesting remarks by L. Arbizzani, in "Il sindacalismo rivoluzionario in Italia nel periodo della seconda internazionale", Ricerche storiche, 5 (1975), pp. I2I-I28. For the Ferrarese, see A. Roveri, Dal sindacalismo a fascismo; P. Corner, Fascism in Ferrara (Oxford, 1975).

98. Gestri, “I9I3: L’USI e lo sciopero generale”.

99. Levy, Gramsci and the Anarchists, pp. 46-50. 
ten-minute late allowances and shop-floor control - rather than bread-andbutter issues. They received widespread support, despite being shunned by FIOM and the local socialists. In this regard principles of autonomy associated with the libertarian "second culture" were still capable of mobilizing workers, thus illustrating Magraw's position quite clearly. A second strike organized by the reformist socialists of FIOM (who coopted the more capable and willing anarchists into their strike committee) followed soon after. In this case, bread-and-butter issues were highlighted but matters of principle were not completely forgotten. Almost concurrently, the USI led a metalworkers' strike in Milan where the syndicalists claimed that their industrial dispute was more "revolutionary" than the cautious reformists of Turin. However, the actual results of contractual negotiation varied little. This seems to add credibility to Stearns's thesis.

Another way to approach this issue is by examining the events leading up to the occupation of the factories in $1920 .{ }^{100}$ It is certainly the case that throughout the summer of 1920 the syndicalists were setting a series of popular agendas, whilst the socialists divided into contentious groups of reformists, maximalists and varieties of communists. The syndicalists garnered widespread support in northern factories in opposition to Giolitti's social insurance legislation, against intervention in Albania, and for the use of direct action to prevent military material reaching the Whites in Russia. The widespread popularity of Malatesta and Borghi witnessed a final upsurge in support for the anarchists and the USI. ${ }^{\text {1or }}$ But during the negotiations in the summer and early autumn of 1920 , the syndicalists themselves turned to reformists to negotiate with the government. Indeed in the fruitless negotiations previous to the occupations of the factories, the reformist FIOM negotiator Bruno Buozzi, used the spectre of syndicalist militancy as a bargaining chip. And Giolitti was not called the "fox of Dronero" for nothing: his Minister of Labour, Arturo Labriola, was his chief negotiator who thoroughly frightened Italian industrialists by not only endorsing Giolitti's proposed vaguely-worded law on workers' control but also by speculating about a future transformation of the Italian capitalist economy into a cooperative commonwealth. ${ }^{\text {I02 }}$

In any case, throughout the biennio rosso, vague ideas about workers' control were present. The first factory occupation was carried out by the interventionist UIL and was hailed by Mussolini as a "productivist" strike. Under pressure from the Christian Democratic popolari, the government had legally sanctioned the occupation of uncultivated lands on large estates in the south. The anarchist labour organizer in the USI, Alberto Meschi,

IOo. The best accounts are still Paolo Spriano's The Occupation of the Factories: Italy I92o (London, 1975), [English translation of L'occupazione delle fabbriche (Turin, 1964)] and Martin Clark's Antonio Gramsci and the Revolution that Failed (New Haven, CT [etc.], 1977).

IOI. Levy, Gramsci and the Anarchists, pp. I2O-I2I.

I02. Clark, Antonio Gramsci, p. I39; Adler, Italian Industrialists, p. I27. 
proclaimed that the marble quarries of Massa-Carrara belonged to the quarrymen, due not to the logic of syndicalist arguments but because of a traditional "premodern" legal dispensation left by the Duchy of Tuscany in the eighteenth century. Traditional custom rather than the class war motivated his formal argument in the press and on the stump. ${ }^{\mathrm{IO} 3}$ Other syndicalist organizers, such as Negro, Giovannetti and Di Vittorio, may have used syndicalist rhetoric but behaved in thoroughly pragmatic and efficient ways when negotiations were at hand. Indeed Apulia, with its pitched battles between organized landless labourers and the landlords' squads, seems to be an excellent example of syndicalist-like class struggle. A more balanced reading of these events has been distorted by the inherent human drama of raw class conflict: the prefects of Apulian provinces were perfectly prepared to negotiate between two sides, and although they did not have the opportunity to read Eric Hobsbawm, I feel certain they would have understood the concept of "collective bargaining through riot". ${ }^{104}$

Even in a postwar era of revolutionary tension, the USI made it clear in one of its almanacs that it too would guarantee limited reformist results. ${ }^{\text {Ios }}$ Here the USI tried to demonstrate its pragmatic and responsible behaviour by proclaiming its support for the reformist campaigns to win an eight-hour day, to raise wages, to prevent night work, to institute sick pay, to eliminate piecework, to increase paid holidays, and to institute the closed shop.

I started this section of the article by contrasting Stearns's position with that of Magraw. This was useful to tease out major issues concerning the theory and practice of Italian syndicalism. I have shown that syndicalist industrial relations was in fact not that different from the socialists', and that socialists, anarchists and syndicalists shared a common "subversive" political culture. In fact it is possible to reconcile Stearns's and Magraw's positions using Gerald Friedman's more recent study of the relationship of the French syndicalists to the French state. ${ }^{\mathrm{I} 06}$ Friedman argues that the syndicalists relied on the state intervention to win strikes and achieved this goal when they mobilized enough workers to force the entry of the state into industrial disputes. In other works, radical mobilization led to reformist collective bargaining once the state intervened. This is all very reminiscent of the radical collective bargaining of Di Vittorio in Apulia or Meschi in Massa-Carrara. However, this symbiotic relationship between the state and

I03. The general tenor of the biennio rosso is discussed in great detail in Vivarelli's magisterial Storia delle origini del fascismo. L'Italia della grande guerra alla marcia su Roma, vols I and 2 (Bologna, 199I). For Meschi's position, see Rolland, Il sindacalismo anarchico.

IO4. Snowden, Violence and Great Estates.

IO5. "I due sindacalismi", in USI, IV congresso nazionale - Roma Io, II, I2 Marzo I922. Programma, relazioni e statuti (Rome, I922), p. 44.

Io6. G.C. Friedman, "Revolutionary Unionism and French Labour: The Rebels behind the Cause; or, Why Did French Revolutionary Syndicalism Fail?”, French Historical Studies, 20 (1997), pp. I5I-I8I. 
the syndicalists or anarchist industrial organizers only functioned in Italy so long as the state's representatives - its prefects and security forces - maintained some semblance of neutrality during industrial disputes. By I92I1922 the forces of law and order in Italy abandoned this position.

\section{CONCLUSION}

The last phase of Italian syndicalism from 1919 to 1926 is finally receiving the attention it deserves. Here I will summarize the historical literature in order to supply a final narrative and analysis of how and why Italian syndicalism was marginalized after 1922.

The growth of the USI during the biennio rosso was stupendous: something in the order of 300,000 to 500,000 workers joined local organizations, but this was piggybacked on an even more amazing growth of the CGL (two million members and perhaps 800,000 in Federterra and 100,000 in FIOM). ${ }^{107}$

The syndicalists' bluff was called in September 1920. During the negotiations over the occupations of the factories they were shunted aside by the reformists of the CGL and FIOM. After the evacuation of the factories the USI was targeted by the government. Blanket arrests of its leadership in the autumn decapitated the movement. In the spring of I92I the movement was mowed down by the fascists in Tuscany and in the Po Valley. Internally the USI was riven by disputes. Armando Borghi had flirted with the Third International, but after the "Twenty-One Points", he denounced Moscow and retired from the front lines, ${ }^{108}$ albeit when his critical position became known is still not clear. We have a fine study that places the USI in the international debate that raged between syndicalists and communists. The effect in Italy was devastating for the structural and ideological coherence of the USI which, by 1922, had divided into four factions: pro-Third Internationalists, the anarchists, the pure and simple syndicalists and finally prosocialist electoralists. For all intents and purposes,the USI ceased to be a viable organization and was finally outlawed in $1925 .^{109}$

The next reduced and clandestine generation of cadres in central Italy and elsewhere were recruited from the dying libertarian "second culture" into the communist or socialist parties. Certain important militants such as

107. Levy, Gramsci and the Anarchists, p. II9.

108. For the fate of the Italian anarchists and syndicalists, see Levy, "Italian Anarchism, I8701926", pp. 74-75. Armando Borghi's ambiguous position is untangled by Antonioli in Armando Borghi, pp. 83-98. Wayne Thorpe places the USI within the general debate about the Third International and international syndicalism, see W. Thorpe "The Workers Themselves": Revolutionary Syndicalism and International Labour, I9I3-I923 (Amsterdam, 1989), chs 3-6.

IO9. For the decline of the USI, see M. Antonioli, "USI ultimo atto: il congresso nazionale di Genova (28-29 guigno I925)”, in idem, Azione diretta e organizzazione operaia, pp. I65-20I. 
Faggi and Negro joined the socialists, while Di Vittorio became a famous leader of the communist-dominated CGL after 1945.

During the "Hot Autumn" of 1969 certain syndicalist-like modes of operation were present, but a recent study which claims a syndicalist influence on striking workers is very misleading. ${ }^{\text {IIO }}$ Young, relatively unskilled southern migrants who were so visible in these years were from peasant backgrounds and knew nothing about the historical and largely regionally specific libertarian "second culture". The radical leadership in 1968/69, worker or student, were either from communist or Catholic backgrounds or attracted to dissident forms of Marxism, so popular in Italy at that time. The disappearance of syndicalism as a major force within the Italian labour movement after 1945 is directly related to the decline of the libertarian "second culture" in its heartland in central and north central Italy during the fascist ventennio. It was precisely here that the Italian Communist Party built its own strongholds. If the repertoire of protest persisted in this area after 1945 (witness the uprisings after the attempted assassination of Togliatti in 1948 or the political crisis after Tambroni tried to admit neofascists into his cabinet in 1960), the ideology of these newer generations of "subversives" had shifted to communism. ${ }^{\text {III }}$ The twenty-year hiatus caused by the fascist dictatorship witnessed the failure of the anarchists or syndicalists to build a new leadership in 1945. The emergence of the welfare state, newer forms of industrial relations based on concertation and the emergence of a consumer society made the traditional concerns of anarchism and syndicalism seem irrelevant. ${ }^{\mathrm{II} 2}$

Explaining the marginalization of syndicalism in Italy after 1945 is also assisted through comparative study. The Spanish case seems to followed a similar trajectory of modernization in the I960s and I970s to that Italy had experienced during the 1950s and I960s, although the Spanish dictatorship lasted nearly twice as long and repression in the wake of the Civil War was bloodier and more dramatic. ${ }^{\mathrm{II}}$ In the Spanish case the communists in the I960s and I970s replaced the Confederación Nacional del Trabajo (CNT)

IIo. H. Partridge, "Labour's Challenge to Capital in Fiat: The Influence of Southern Immigrants in a Changing Industrial Culture", Labour History Review, 67 (1997), pp. 7I-IOI.

III. For the communist tradition of sovversivismo, see E. Mannari, "Tradizione sovversiva e comunismo durante il regime fascista, 1926-43", Annali della Fondazione G. Feltrinelli, 20 (19791980), pp. 837-874; F. Andreucci and A. Pescarolo (eds), "La formazione delle regioni rosse in Italia: il caso della Toscana", in F. Andreucci (ed.), Gli spazi del potere. Aree, regioni, Stati: le coordinate territoriali della storia contemporanea (Florence, I989), pp. I27-I34; T. Abse, "Italy", in S. Berger and D. Broughton (eds.), The Force of Labour: The Western European Labour Movement and the Working Class in the Twentieth Century (Oxford, 1995), pp. 137-170.

II2. I discuss the decline of Italian anarchism as a mass social movement in Levy, "Italian Anarchism, I870-1926", pp. 74-75.

II3. For the Spanish case, see S. Balfour, Dictatorship, Workers and the City: Labour in Greater Barcelona since 1939 (Oxford, 1989); J. Casanova, De la calle al frente. El anarcosindicalismo en España, 193I-I939 (Barcelona, 1997), pp. 238-246. 
as the most militant force within the illegal trade union movement and later in the 1980s the socialists occupied most of the political space in the noncommunist left.

In democratic France syndicalism largely embraced technological reformism by 1918 and then was marginalized by communism. ${ }^{\text {II4 }}$ Yet here the decline was in some respects slower. One study shows the persistence of syndicalism within specific municipal political cultures in the interwar period and another has recently demonstrated the presence of libertarian syndicalism during the Popular Front in the 1930s. ${ }^{\text {II }}$ Furthermore, unlike Italy, there is something to be said for the presence of anarchist and syndicalist currents within the great strikes of May 1968, particularly in certain distinctive settings such as Nantes.

In Italy, if postmodern social movements rediscovered the anarchist tradition after 1968/69, their audience inhabited another universe from the artisans, peasants and workers of liberal Italy. However, one of the unintended results of 1968 and 1969 was the creation of a new generation of labour and social historians associated with the shift in the political cultures of Italy in the r970s and 1980s which in turn led to a lessening of the politicized grip by liberal/communist/Catholic historians upon the study of the Italian labour movement before 1926, and thus allowing for more nuanced accounts to emerge during the past three decades.

II4. Tucker, Revolutionary Syndicalism and the Public Sphere, chs 7 and 8.

II5. K.E. Amdur, Syndicalist Legacy: Trade Unions and Politics in Two French Cities in the Era of World War (Urbana, IL, I986); D. Berry, "'Fascism or Revolution!': Anarchism and Antifascism in France, 1933-39”, Contemporary European History, 8 (1999), pp. 5I-7I. 